\title{
Polycyclic Aromatic Hydrocarbon (PAH) Pollution and its Associated Human Health Risks in the Niger Delta Region of Nigeria: A Systematic Review
}

Samuel Appiah Ofori ${ }^{* 1,2,3,4}$, Samuel Jerry Cobbina ${ }^{2}$, Abubakari Zarouk Imoro², Dzigbodi Adzo Doke ${ }^{2}$, Thomas Gaiser $^{5}$

1. Département de Biologie des Organismes, Faculté des Sciences, Université Libre de Bruxelles, Brussels, Belgium

2. Department of Environment and Sustainability Studies, Faculty of Natural Resources and Environment, University for Development Studies, Tamale, Ghana.

3. Department of Biology, Faculty of Science and Bioengineering Sciences, Vrije Universiteit Brussel, Brussels, Belgium

4. Dipartimento di Biologia, Università degli Studi di Firenze, Firenze, Italia

5. Institute of Crop Science and Resource Conservation, University of Bonn, Bonn, Germany

E-mail: ofori496@gmail.com, scobbina@uds.edu.gh

ORCID: https://orcid.org/0000-0002-8462-5264

\begin{abstract}
The frequent incidents of oil spills and other forms of pollution arising from crude oil exploration and exploitation (OEE) in the Niger Delta have caused several investigations on Polycyclic Aromatic Hydrocarbons (PAHs) pollution. This study aimed at developing a comprehensive report on PAH pollution and its human health risks recorded in the Niger Delta. Studies were extracted from Google Scholar, PubMed, and ResearchGate using a defined selection criterion. The quality of each study was assessed using the Newcastle - Ottawa Scale. Thirtyeight studies were selected with the majority reporting on PAH pollution in aquatic environments. Across all the selected studies, the total number of PAHs recorded ranged from 7 to $28 \mathrm{PAH}$ congeners. Also, PAH potential sources reported in the studies were of pyrogenic and petrogenic sources. PAH concentrations recorded in water, sediment, aquatic organisms (fish and shrimp), soil, dust, and crop samples ranged from below detection limit (BDL) to $450 \pm 117.9 \mathrm{mg} / \mathrm{L}, \mathrm{BDL}$ to $1821.5 \mathrm{mg} / \mathrm{kg}, 0.005$ to $1.098 \mathrm{mg} / \mathrm{kg}$, ND to $4154 \pm 3461 \mathrm{mg} / \mathrm{kg}, 165.1$ to $1012 \mathrm{mg} / \mathrm{kg}$, and 0.020 to $3.37 \mathrm{mg} / \mathrm{kg}$, respectively. Majority of the selected studies reported PAH levels which were higher than the permissible limits. Incremental Lifetime Cancer Risk (ILCR) assessment of PAHs in samples ranged from low to high via ingestion and dermal routes of exposure to humans. It is recommended that the Federal Government of Nigeria promotes environmentally friendly operations of OEE. Future studies should focus on PAH pollution in farmlands, ambient air and the associated human and ecological health risks.
\end{abstract}

Keywords: Oil exploration and exploitation, Gas flaring, Environmental pollution, PAH sources, Incremental lifetime cancer risk 


\section{Highlights}

- The Niger Delta is one of the most polluted regions on earth with high international recognition.

- Most PAH records in its aquatic and terrestrial environments are higher than permissible limits.

- PAH pollution poses low to high cancer risks to humans via ingestion and dermal exposure routes. 


\subsection{Introduction}

Nigeria is known to be the leading producer of oil across the African continent since 2019 with a production amount of 101.4 million metric tonnes (Faria 2020) which occurs in the Niger Delta. The country also holds the eleventh position of the top crude oil-producing countries in the world (Nriagu et al. 2016). Nigeria's Niger Delta is identified as the largest delta in Africa, which is also listed as the third-largest delta in the world (Obida et al. 2018). The Niger Delta is situated in southern Nigeria with its main water source being the River Niger, which also originates from the central part of Nigeria. As part of ten major marine and wetland ecosystems in the world, the Niger Delta is known to possess several creeks, lakes, rivers, estuaries, mangrove ecosystems, forests, and other ecological features (Obida et al. 2018). There are also human settlements in the Niger Delta including states, metropolis, cities, and local government areas (LGAs) (Ofori et al. 2020a).

The Niger Delta is identified as the main region noted for the production of oil and gas in Nigeria (Fig. 1). The exploration of oil in the Niger Delta commenced in the year 1956 when the first oil well was drilled at Oloibiri (Sojinu et al. 2010). Oil exploration and exploitation (OEE) operations currently occur in more than $50 \%$ of Niger Delta's total area (Nriagu et al. 2016). These operations which generate major foreign exchange and revenue for the country, have led to a profusion of access roads, oil pipelines, oil wells, gas flaring, wastes generated from dredging, and flow stations that are commonly found close to homesteads, schools, and farms within or close to hosting communities (Nriagu et al. 2016).

\section{Fig. 1 here}

It is common to find oil spill sites in the Niger Delta where in most cases are reported to be caused by multinational oil companies (MNOCs) involved in major OEE operations and vandalism of oil pipelines occurring in the region (Amnesty International 2018). Oil spills that occurred in the Niger Delta during the last five decades are estimated to be over two billion litres of oil (Agbonifo 2016). This implies that in each of these years, about 40 million litres of oil were released into the Niger Delta environment area through incidences of oil spills (Agbonifo 2016). Besides, natural gas which is a by-product of petroleum production is also frequently flared into the atmosphere (Ite and Ibok 2013), contributing greatly to the pollution levels in the region. Subsequently, the Niger Delta is identified in the list of the top five oil-polluted regions in the world (Obida et al. 2018; Amnesty International 2018).

The operations related to the exploration and exploitation of oil in the Niger Delta are indicated as those that pose significant negative impacts on the natural environment and society (Ite et al. 2013). These negative impacts 
include: (i) atmospheric pollution related to the burning and venting of natural gas (Ite et al. 2013); (ii) marine ecosystem pollution resulting in negative impacts on biota, and indirect impacts on tourism, fisheries and other livelihoods of the host communities (Iniaghe et al. 2013; Osuagwu and Olaifa 2018); (iii) surface and groundwater pollution (Ite et al. 2018); (iv) introduction of socio-economic issues and degradation of the cultural values and resources of host communities (Iniaghe et al. 2013); (v) degradation of lands, issues of food quality and decline in agricultural activities (Inoni et al. 2006); and vi) increased cases of disease symptoms and environmental distress (Nriagu et al. 2016).

The pollution events occurring as a result of the OEE operations in the Niger Delta have led to the release of harmful chemicals such as Total Petroleum Hydrocarbons (TPHs), Polycyclic Aromatic Hydrocarbons (PAHs), heavy metals, and other persistent organic pollutants into its terrestrial and aquatic environments. This situation has largely presented environmental and human health issues of global concern (Emoyan et al. 2008a, b; United Nations Environment Programme 2011).

Aside from the OEE operations, which are considered as the major sources of pollution in the Niger Delta, there has been an increase in the number of allied industries and other anthropogenic activities. These include the production of chemical fertilisers, processing of rubber and asphalt, and activities of landfill sites, petrochemical industries, power stations, urbanisation, among others. These activities together with the OEE operations have greatly promoted several studies on the increased levels of PAH pollution in the Niger Delta since the year 2005 (Abbas and Brack 2005; Inam et al. 2015; Dosunmu et al. 2016; Ofori et al. 2020a).

PAHs are described as a group of organic compounds which are formed and released into the natural environment during incomplete combustion of organic materials such as crude oil, coal, wood, and even smaller organic molecules such as methane (Russell 2013; Ofori et al. 2020a, b). PAHs are frequently present across various components of the natural environment (soil, air, water, biota) with their traces also recorded in different food items. Hence, they are classified as ubiquitous chemicals in the environment (Ofori et al. 2020a, b). There are over 100 PAH congeners (including parent PAHs and alkylated derivatives) identified in the environment. The United States Environmental Protection Agency (USEPA 2014) has, however, indicated 16 of them as priority pollutants under its Clean Water Act (1977) due to the possible risks they pose to human and ecological health. They are chrysene, acenaphthylene, acenaphthene, phenanthrene, anthracene, fluoranthene, fluorene, pyrene, naphthalene, benzo[b]fluoranthene, benzo[k]fluoranthene, benzo $[a]$ pyrene, benzo $[a]$ anthracene, $\operatorname{dibenz}[a, h]$ anthracene, benzo $[g, h, i]$ perylene, and indeno[1,2,3-cd]pyrene (USEPA 2014). The European 
Commission (EC 2013) however includes eight (naphthalene, benzo[b]fluoranthene, benzo[k]fluoranthene, benzo $[a]$ pyrene, anthracene, fluoranthene, indeno $[1,2,3-c d]$ pyrene, and benzo $[g, h, i]$ perylene) of these PAH congeners as priority substances under its Water Framework Directive.

The properties of PAHs are determined by the number of benzene rings and their molecular mass (Stogiannidis and Laane 2015). PAH congeners that possess four or more benzene rings are described as high molecular weight (HMW) PAHs, while congeners with two or three benzene rings are described as low molecular weight (LMW). For instance, anthracene, phenanthrene, naphthalene, fluorene, which possess less than four benzene rings are categorised as LMW PAHs, whereas benzo[a]pyrene, benz $[a]$ anthracene, pyrene, chrysene, and indeno[ $[1,2,3$ $c d$ ]pyrene with four or more benzene rings are described as HMW PAHs (Stogiannidis and Laane 2015; Ofori et al. 2020a, b). Benzo(a)pyrene [B(a)P], a well-known PAH congener, is used to represent PAHs as it is considered by the International Agency for Research on Cancer (IARC) as a known carcinogen, implying its harmful effects on human and animal health (IARC 2016). Also, since PAHs are commonly occurring in the environment as mixtures, an identification of $\mathrm{B}(\mathrm{a}) \mathrm{P}$ in a sample or product can be used to describe the existence of other PAHs (German Federal Environment Agency 2012).

In aquatic environments, sediments and aquatic organisms are mostly described as the eventual sinks of PAHs (Mekonnen et al. 2015). Since PAHs are lipophilic with high chemical stability, they can find their way into organs of aquatic organisms such as fish and molluscs through their ingestion of PAH-polluted organic matter or dermal contact with sediments polluted with PAHs, thereby accumulating in their fatty tissues. Fish and molluscs are therefore used as suitable indicators of PAH pollution in aquatic environments (Nyarko et al. 2011; Ofori et al. 2020a).

In terrestrial environments, cities and communities with increasing growth in the human population and urbanisation are reported to also experience an increase in vehicular traffic and industries resulting in a high degree of PAH pollution in the environment (Safo-Adu et al. 2014; Chen et al. 2017). Moreover, vehicles without proper maintenance are generally identified to release increased levels of especially HMW PAHs through exhaust fumes which readily adsorb onto soil particles (Obiri et al. 2011).

The widespread characteristic of PAHs and their ability to cause cancer or toxic effects on living organisms in the environment constitute a significant risk to human health. The release of PAHs can result in their uptake into the body of humans and other mammals through ingestion of contaminated food or water, inhalation of polluted air, and dermal contact with polluted soil. The toxic effects that may occur as a result of public exposure to PAHs are 
short- and long-term health effects, which are commonly associated with breathing and cardiovascular disorders (Błaszczyk et al. 2016; Ofori et al. 2020b).

Due to the high levels of PAH pollution occurring in the Niger Delta and their associated health risks, several studies have been conducted by collecting samples from different environments of the Niger Delta. Most of these environments include rivers, creeks, dumpsites, OEE sites, automobile repair shops, agricultural farms, and other urban areas (Abbas and Brack 2005; Ana et al. 2009; Sojinu et al. 2010; Nganje et al. 2011; Olawoyin et al. 2012; Oyo-Ita et al. 2012; Adedosu et al. 2012; Osuji et al. 2012; Nduka et al. 2013; Nganje et al. 2014; Ogoko 2014; Asagbra et al. 2015; Inam et al. 2015; Nwineewii and Marcus 2015; Davies and Abolude 2016; Dosunmu et al. 2016; Nwaichi et al. 2016; Iwegbue et al. 2016; Ekanem et al. 2019; Ihuoma et al. 2020).

It is commendable to see that several studies have addressed PAH pollution in the Niger Delta, however, these studies are isolated. This situation limits the ease of access and use of these studies by the public and even the scientific community, and further breeds a lack of general understanding of PAH pollution in the Niger Delta. It is, therefore, timely and important to address the above issues through a systematic review. The current study serves as a comprehensive report on the degree of PAH pollution in the Niger Delta and its associated human health risks. It also critically reviews the quality of data presented by the various selected studies, and also provides recommendations necessary for tackling this environmental issue in the Niger Delta.

\subsection{Methods}

\subsection{Criteria for Search and Selection of PAH-related Studies}

The Preferred Reporting Items for Systematic Reviews and Meta-Analysis (PRISMA) methodology developed by Moher et al. (2009) was used in the preparation of this systematic review (Fig. 2). The search for studies and their selection took place from February to September 2020 using the databases: Google Scholar, PubMed and ResearchGate. The search and selection process extracted studies that have been published from 2005 to 2020. The keywords used in the search process were: "PAHs or Polycyclic Aromatic Hydrocarbons in Niger Delta, Nigeria".

Based on the different studies that were extracted from the databases, the following categories of studies were used to aid in the selection process: PAHs in aquatic environments, PAHs in dust and soil, and PAHs in crops. TheThe extracted studies were then assessed for relevance or not. Studies that only looked at bioremediation and 
other management strategies of PAHs were not considered relevant since such studies did not present the objective of assessing the concentrations of PAHs in samples. Concerning studies that were published twice, researchers decided to choose the one that was most recently published with adequate information on identified PAHs (Fig. 2).

Fig. 2 here

\subsection{Data Extraction and Quality Assessment}

After suitable studies were selected, a set of information describing each study was extracted: authors, year of publication, aim of study, area of study, period of sampling, type(s) and number of samples collected, analytical technique, number and concentrations of PAHs identified, and potential sources of PAH pollution in the study area.

The quality process was conducted then by adapting the Newcastle-Ottawa Scale (NOS) developed by Wells et al. (2009) to suit the scope of this study. A set of eight signalling questions were used to provide an overall quality score for each study that was selected (Table 1). The signalling questions inquired whether selected studies reported on period of sampling, control samples, sampling technique, clean-up process, QA/QC methods, all objectives achieved, PAH sources, and mean PAH levels. For each signalling question, a "Yes" or "No" response was given on behalf of each of the selected studies.

\subsection{Results}

\subsection{Study Selection and Quality Assessment}

The criteria employed in selecting and excluding the extracted studies is summarised using an adapted PRISMA flow diagram (Fig. 2). The number of studies that were extracted was 59 in total. Among these, 38 studies were selected as suitable for this analysis while the remaining 21 were excluded. Among the 21 studies that were excluded, three were duplicate studies, while nine were found to be unrelated to this work after their abstracts were reviewed. The remaining nine studies were also excluded since they did not meet the criteria used in selecting suitable studies. 
The results of the signalling questions used in assessing the quality of the selected studies are presented in Table 1 and Fig. 3. Table 1 provides the individual scores for each study that was selected, while Fig. 3 presents the percentage of selected studies that responded with a "Yes" or a "No" to each of the signalling questions. The majority of the selected studies responded a "Yes" to six of the signalling questions: i.e., period of sampling indicated, clean-up process conducted, QA/QC conducted, all objectives achieved, reports on PAH sources, and reports on mean PAH levels (Fig. 3). However, considering the individual scores of the selected studies, ten studies answered "Yes" to 6-7 out of the 8 signalling questions (i.e., scoring 5/8 - 7/8), while 28 studies answered "Yes" to 2-5 out of the 8 signalling questions (i.e., scoring $2 / 8-5 / 8$ ).

Table 1 and Fig. 3 here

\subsection{Sources and Levels of PAHs in the Niger Delta}

\subsubsection{PAHs in Aquatic Environments}

Results of selected studies that reported on PAH pollution in different aquatic environments are provided in Table 2. The USEPA under the National Primary Drinking Water Act sets a legally permissible limit on the level of benzo $[a]$ pyrene in drinking water to be $0.002 \mathrm{mg} / \mathrm{L}$ (USEPA 2009). The Agency for Toxic Substances and Disease Registry (ATSDR) sets a permissible range limit on the level of PAHs occurring in surface water samples to be 0.004 to $0.024 \mathrm{mg} / \mathrm{L}$ (ATSDR 1995). The EC (2006) has also established a permissible limit for the levels of benzo $[a]$ pyrene and the sum of 4 PAHs present in fresh molluscs to be $0.005 \mathrm{mg} / \mathrm{kg}$ and $0.030 \mathrm{mg} / \mathrm{kg}$, respectively. For fresh fish samples, a permissible limit of $0.002 \mathrm{mg} / \mathrm{kg}$ of benzo[ $[\mathrm{a}]$ pyrene was implemented (EC 2006). Out of the 20 studies that reported on PAH pollution in aquatic environments (water, fish, and shrimps), 19 of them recorded PAH concentrations which were higher than the permissible limits provided by USEPA (2009), ATSDR (1995) and the EC (2006) (Fig. 4).

\section{Table 2 here}

\subsubsection{PAHs in Dust and Soil}

Table 3 provides a summary of the selected studies that reported on PAH pollution in dust and soil samples in the Niger Delta. The Federal Soil Protection and Contaminated Sites Ordinance (FSPCSO 1998) of Germany introduced a precautionary value for benzo[a]pyrene in agricultural soils to be $1 \mathrm{mg} / \mathrm{kg}$ (GFEA 2012). For urban 
area soils (commercial, industrial, and recreational facilities), a test value range of $10-12 \mathrm{mg} / \mathrm{kg}$ for benzo[a]pyrene is used as a basis for controlling pollution of urban soils (GFEA 2012). Out of the 18 studies that reported on PAH pollution in dust and soil samples, 10 of them recorded PAH concentrations which were higher than the permissible limits provided by the FSPCSO (1998) (Fig. 4).

\section{Table 3 here}

\subsubsection{PAHs in Crops}

The results of studies reporting on PAH levels in crops collected from agricultural lands located nearby oil exploration sites are provided in Table 4. The European Commission (EC) under the Regulation No. 1881/2006 (EC 2006) implemented a permissible limit of $0.001 \mathrm{mg} / \mathrm{kg}$ for PAH contamination in ready-to-eat food items (European Food Safety Authority 2008). All three studies which reported on PAH contamination in crops recorded PAH concentrations which were higher than the permissible limits provided by the EU (Fig. 4).

\section{Table 4 and Fig. 4 here}

\subsection{Human Health Risk Assessment of PAH Pollution in the Niger Delta}

Among the several PAHs identified in the environment, the 16 USEPA PAHs indicated by the USEPA as priority pollutants have been used in several studies for assessing human health risks of PAH exposure in samples. Since PAHs are ubiquitous, the models used in human health risk assessments pay attention to the major pathways (ingestion, inhalation, and dermal contact) through which PAHs get into the human body.

Most studies report on either one or both of non-carcinogenic (toxic) and carcinogenic risks of PAHs on human health. For carcinogenicity risks of PAHs on human health, it is common to find that majority of studies use the Incremental Lifetime Cancer Risk (ILCR) model developed by the USEPA in 1991 (Ofori et al. 2020a). The model depends on some factors such as type of sample, pathways of exposure, concentrations of individual PAHs, carcinogenic equivalents, particle emission factor, exposure duration, exposure frequency, dermal adherence factor, slope factor, ingestion rate, inhalation rate, average lifetime, body weight, and age of the individual, among others (Yang et al. 2015; Ofori et al. 2020b). The USEPA defines an ILCR guideline range between $10^{-6}$ and $10^{-4}$ to be indicative of potential risk (Ofori et al. 2020a). 
Studies that focus on non-carcinogenic effects of PAH exposure to human health make use of hazard quotient (HQ) and hazard index (HI) which depends on the estimated/chronic daily intake (EDI or CDI) and reference dose (RfD) of PAHs in samples. The EDI or CDI employs most of the factors used in the ILCR except the slope factor. When the HI, which is the summation of individual HQs, is greater than one, it indicates a potential noncarcinogenic human health risk (Inam et al. 2015; Tongo et al. 2017). The results of carcinogenic (ILCR) and noncarcinogenic (HI) risks of PAH exposure to human health reported in the selected studies are recorded in Table 5.

\section{Table 5 here}

\subsection{Discussion}

\subsection{Summary of Major Findings}

The current study presents a systematic review of a total of 38 selected studies conducted on the occurrence of PAH pollution in the Niger Delta. All selected studies reported varying levels of PAHs in samples. Most of the studies went further to assess the potential sources of PAHs identified in the collected samples. Generally, the total number of PAH congeners identified in samples across all studies ranged from seven to 28 . Twenty-five studies out of the 38 that were selected reported on the 16 USEPA PAHs recorded in aquatic environments, dust and soil and crops, making the 16 USEPA PAHs the most identified set of PAHs present in the Niger Delta (Fig. 5).

\section{Fig. 5 here}

The majority (53\%) of selected studies reported on PAH pollution occurring in aquatic environments such as rivers, creeks, lakes, and estuaries. The samples collected in the studies included water, sediments, fish and shrimps. For water and sediment samples, studies reported levels of PAHs ranging from BDL to $450 \pm 117.9 \mathrm{mg} / \mathrm{L}$ and BDL to $1821.5 \mathrm{mg} / \mathrm{kg}$, respectively. PAH concentrations recorded for fish and shrimps ranged from 0.005 to $0.1098 \mathrm{mg} / \mathrm{kg}$ across the selected studies.

Considering studies conducted on PAH pollution occurring in dust and soil samples collected from various regions of the Niger Delta, 18 (including 3 already reported studies in the category of aquatic environments) out of the 38 studies were identified. The majority of the studies focused on PAH pollution occurring in soil samples collected from oil spill sites, leaking pipelines, and polluted farm/forest lands. The total PAH concentrations recorded across these sampling sites ranged from ND to $4154 \pm 3461 \mathrm{mg} / \mathrm{kg}$. Out of the 38 selected studies, three reported on PAH 
contamination occurring in crops (cassava tubers, African oil bean, and mushrooms) harvested from farmlands located within areas with reported incidences of oil spills or pipeline leakages. The total PAH concentrations recorded ranged from 0.020 to $3.37 \mathrm{mg} / \mathrm{kg}$.

The use of PAH isomeric/molecular ratios and other methods (like Principal Component Analysis, cross plots, and the percentage of LMW and HMW PAHs) by the various studies in assessing the potential sources of PAHs in the aquatic environments and dust and soil samples showed that the major sources of the PAH pollution were of petrogenic (petroleum) and pyrogenic (combustion) origins. Studies conducted on PAH contamination in crops did not report on the potential sources of PAHs in samples. Petrogenic sources included incidences of oil spills and oil pipeline leakages arising from either OEE operations, inland port and harbour activities, and vandalising and illegal bunkering of crude oil. For pyrogenic sources, the flaring of natural gas associated with crude oil was implicated as the major contributor.

Eight of the selected studies conducted a human health risk assessment of PAH pollution in samples for both children and adult populations. Out of the 8 studies, five used soil and/or dust, two used water, sediment, and fish samples, and one used mushrooms, as samples. Only three of the eight studies reported on both carcinogenic and non-carcinogenic risks of PAH pollution to human health (Table 5). Considering non-carcinogenic risks, 2 studies recorded an HI which was less than one. For carcinogenic risks, the range of ILCR via the inhalation pathway of exposure for children and adult populations across all the studies was from $8.79 \times 10^{-15}$ to $2.17 \times 10^{-8}$ and from $3.53 \times 10^{-14}$ to $2.39 \times 10^{-8}$, respectively. For dermal pathway of exposure, the ILCR recorded for children and adult populations across all the studies ranged from $8.19 \times 10^{-12}$ to $8.9 \times 10^{-2}$ and from $7.28 \times 10^{-6}$ to $8.74 \times 10^{-3}$, respectively. The range of ILCR via the ingestion exposure pathway recorded for children and adult populations across the studies were from $3.16 \times 10^{-7}$ to $3.54 \times 10^{-2}$ and from $4.35 \times 10^{-11}$ to $1.69 \times 10^{-2}$.

In reference to the ILCR guideline $\left(10^{-6}\right.$ to $\left.10^{-4}\right)$ defined by the USEPA (1991), it can be deduced that PAH exposure via inhalation as recorded across the eight selected studies does not present any carcinogenic risks. However, considering ingestion and dermal contact as pathways of PAH exposure, the recorded ILCRs in most of the selected studies presented low to high carcinogenic risks (Table 5).

\subsection{Discussion of Major Findings}

In assessing the quality of studies using the Newcastle - Ottawa Scale (NOS), limitations of the studies mainly resulted from the sampling technique, the analytical techniques and reported results (Table 1 and Fig. 3). It was 
found that about $42 \%$ of the selected studies during their sampling process only collected single samples instead of duplicates or triplicates from each sampling point. Using a single sample per sampling point does not provide representative information of the PAH pollution occurring at a sampling point (Zhang 2006). In this way, such studies could not provide mean values of the total concentration of PAHs identified in collected samples. Moreover, some studies did not provide comprehensive information on how the sampling process was undertaken. For instance, about $50 \%$ of the selected studies did not state how long sampling lasted. Moreover, about $74 \%$ of the selected studies did not include control samples in their sampling process. Sixty-six per cent of the selected studies did not indicate the type of sampling technique that was employed in their sampling process. All of these brings about the lack of power to find significance in reported PAH concentrations in samples (Zhang 2006).

It was found that about $79 \%$ of the selected studies conducted a clean-up process for sample extracts before PAH analysis. A clean-up process on sample extracts helps to remove co-extractives or unwanted particles which may cause changes in the actual concentrations of the identified PAHs in the samples (Zhang 2006). Also, about $42 \%$ of the selected studies did not conduct QA/QC measures during sample analysis. QA/QC measures are known to be relevant in promoting the accuracy and precision of studies, and thus, renders studies without it untrusted (Zhang 2006). The use of PAH isomeric ratios and multivariate analysis for the assessment of PAH sources in samples are useful in understanding the occurrence and levels of PAHs in the environment. About $61 \%$ of the selected studies reported the potential sources of PAHs in collected samples.

To assess the degree of PAH pollution occurring in the selected studies, the recorded range of PAH concentrations for each of the sample categories reported in this study were compared to regulatory limits provided by different governmental organisations (Fig. 4). Considering water samples, the recorded range of PAH concentrations (BDL to $450 \pm 117.9 \mathrm{mg} / \mathrm{L})$ was about 15,000 times higher than the permissible limit $(0.004$ to $0.024 \mathrm{mg} / \mathrm{kg})$ indicated by the ATSDR (1995). For fish and shrimp samples, the recorded range of PAH concentrations (0.005 to 0.1098 $\mathrm{mg} / \mathrm{kg}$ ) was 1000 times higher than the permissible limits set by the EC for benzo[a]pyrene and 4 PAHs in fish and molluscs samples. For dust and soil samples, the range of PAH concentrations (ND to $4154 \pm 3461 \mathrm{mg} / \mathrm{kg}$ ) recorded in this study was over 300 times higher than the permissible limits $(10-12 \mathrm{mg} / \mathrm{kg})$ defined by the FSPCSO (1998). Lastly, the range of PAH concentrations in crops $(0.020$ to $3.37 \mathrm{mg} / \mathrm{kg})$ reported in this study was over 3000 times higher than the permissible limit $(0.001 \mathrm{mg} / \mathrm{kg})$ defined by the EC (2006) for PAH contamination in ready-to-eat food items. 
The outcomes of the comparisons conducted for the levels of PAHs in each of the sample categories with the permissible limits defined by the governmental organisations reveals that there is a high degree of PAH pollution occurring in the Niger Delta. The human health risk assessment conducted by some of the selected studies also revealed that the public was exposed to low to high cancer risks via dermal and ingestion pathways of exposure (Table 5). This implies that the continual exposure of high PAH levels experienced by individuals located in the Niger Delta has the potential to lead to toxicological and carcinogenic effects on their health.

\subsection{Limitations of Study}

There were only three categories from which this systematic review of the selected studies was prepared. They included PAHs in aquatic environments, PAHs in dust and soil, and PAHs in crops. Researchers were not able to identify any PAH-related study in the Niger Delta that focused on PAH pollution occurring in other sample categories such as indoor/outdoor air and ready-to-eat food items. Such studies were not available in the databases searched. Out of the 38 selected studies, 20 were in the category of PAHs in aquatic environments, 15 in the category of PAHs in dust and soil, and three in the category of PAHs in crops. The few numbers of studies recorded under the category of PAHs in crops makes it inefficient to provide a general idea of PAH levels present in crops cultivated in the Niger Delta.

Considering the number of PAH congeners reported by the selected studies, the majority ( 25 out of 38 ) identified the 16 USEPA PAHs (USEPA 2014) in their samples, with the remaining focusing on other groups of PAHs. The 16 USEPA PAHs are identified as the most reported PAHs across different studies in the world. This is a result of their potential to present toxic and carcinogenic effects on living organisms, persistence in the environment, and the ease of analysing and identifying them in samples (Hussar et al. 2012; Andersson and Achten 2015a). However, as relevant as the 16 USEPA PAHs may be, many researchers in the ecotoxicology of Polycyclic Aromatic Compounds (PACs) have pointed out that focusing only on the 16 USEPA PAHs may limit our ability to adequately assess and comprehensively describe the fate and behaviour of PAHs in different components of the environment (Andersson and Achten 2015a). Considering then this remark by Andersson and Achten (2015b), it is relevant to point out that the majority of the selected studies in this systematic review may have missed out on providing sufficient data on the issue of PAH pollution in the Niger Delta.

Most of the results of total PAHs concentrations recorded in samples were reported in diverse measuring units. For instance, studies which recorded PAHs in soil or sediment samples reported the total concentrations in either 
$\mathrm{ng} / \mathrm{g}$ or $\mathrm{mg} / \mathrm{kg}$ or $\mu \mathrm{g} / \mathrm{kg}$, and studies which recorded PAHs in water samples reported them in either $\mathrm{mg} / \mathrm{L}$ or $\mathrm{ng} / \mathrm{L}$ or $\mu \mathrm{g} / \mathrm{L}$. These differences in units of measurements make the extensive comparison between studies less efficient as readers would have to make conversions of recorded values beforehand. It is also key to indicate since a high number (42\%) of the selected studies did not follow QA/QC protocols during sample analysis, their results may be rendered less reliable.

The assessment of the potential sources of PAHs recorded in samples were conducted using different indices of PAH source identification which included PAH diagnostic/isomeric ratios, Principal Component Analysis, and the predominance of either LMW or HMW PAHs. PAH isomeric ratios or the predominance of LMW/HMW PAHs are proven to be simple methods for assessing the potential sources of PAHs. However, PAH ratios do change remarkably from the source of pollution to the environmental media under study through existing differences in water solubility and volatility between two PAHs of the same molecular weight, thus making the identified sources less accurate (Biache et al. 2014; Wang et al. 2016). This situation is also common with the use of LMW/HMW PAH diagnostic ratios, as LMW PAHs are known to be very unstable due to the influence of environmental factors such as photodegradation and volatilization, making them highly affected by flow mechanisms in the aquatic environment (Adeniji et al. 2017). These factors, therefore, make the PAH sources identified by studies which used PAH diagnostic ratios less robust.

Moreover, each of the selected studies presented different techniques in sample extraction, sample clean-up and PAH analysis in sample extracts. Sample extraction methods used by the different selected studies included: Accelerated Solvent Extraction, Ultrasonication Extraction, Microwave Extraction, Liquid to Liquid Extraction, and Soxhlet Extraction, among others. The methods used for PAH analysis included: Gas Chromatography - with Flame-Ionization Detection (GC-FID) and Gas Chromatography-Mass Spectrometry (GC-MS). Each of these methods operates differently with distinct levels of accuracy. For instance, ultrasonication extraction is a quick extraction method, however, its efficiency is typically low when used for studies which require a high extraction efficiency of samples with a very low concentration of PAHs (Wang et al. 2016).

\subsection{Conclusions}

This study reports on relevant information on the occurrence, concentrations, sources and associated potential human health risks of PAHs in the Niger Delta using reported results from selected studies. Majority of the selected studies reported PAH pollution occurring in water, sediments, fish and shrimp samples from the aquatic 
environment of the Niger Delta. The PAHs identified in samples from the aquatic environments were of both petrogenic and pyrogenic sources. Moreover, higher concentrations of PAHs recorded across the sample categories were above the permissible limits indicated by governmental organisations. The studies which reported on ILCR of PAHs in samples recorded low to high cancer risks via ingestion and dermal routes of exposure. This indicates the urgency needed by the Federal Government of Nigeria in collaboration with the National Oil Spill Detection and Response Agency (NOSDRA), the Niger Delta Development Commission (NDDC), Department of Petroleum Resources (DPR), Nigerian Federal and States' Ministry of Environment, and other NGOs involved in environmental conservation to pay adequate attention to the pollution arising from OEE operations in the Niger Delta. It is further recommended that research studies on PAHs in the Niger Delta are extended to farmlands (crops, livestock) and the ambient air, within the vicinities of oil exploration companies, with a greater focus on the assessment of potential ecological and human health risks. Researchers are encouraged to report more on the other PAH groups such as alkylated PAHs, considering their potential environmental relevance, since using only the 16 USEPA PAHs does not provide a complete view of the environmental and human health impacts of PAH pollution. Researchers in this field of study are also urged to make use of two or more indices (including multivariate analysis) for PAH source identification and also develop the practice of including QA/QC measures in their studies to promote the robustness and confidence of their results. 


\section{Declaration}

Funding: Not applicable

Conflicts of interest: Authors have no existing conflict of interest

Data availability: Not applicable

Code availability: Not applicable

Authors' contribution: Samuel Appiah Ofori: Conceptualisation, writing, search and selection of studies, analysis and review. Samuel Jerry Cobbina: Conceptualisation, search and selection of studies, review and editing. Abubakari Zarouk Imoro: Quality assessment of selected studies, review and editing. Dzigbodi Adzo Doke: Quality assessment of selected studies and review. Thomas Gaiser: Conceptualisation, quality assessment of selected studies and review.

\section{Acknowledgements}

Authors extend their gratitude to David Appiah Boateng for his review and comments which were useful in finalising the writing of the manuscript. The authors are also thankful to the anonymous reviewers whose comments were essential in making this research a better one, ready for public use. 


\section{References}

Abbas AO, Brack W (2005) Polycyclic aromatic hydrocarbons in Niger Delta soil: contamination sources and profiles. Int. J. Environ. Sci. Tech 2:343-352

Adedosu TA, Adedosu HO, Sojinu OS (2012) N-Alkanes and polycyclic aromatic hydrocarbons (PAHs) profile of soil from some polluted sites in Niger Delta, Nigeria. Environ Earth Sci 68:2139-2144. https://doi.org/10.1007/s12665-012-1897-3

Adeniji AO, Okoh OO, Okoh AI (2017) Analytical methods for polycyclic aromatic hydrocarbons and their global trend of distribution in water and sediment: a review. In: Zoveidavianpoor M (ed) Recent Insights in Petroleum Science and Engineering. Intechopen, pp 393-428. http://dx.doi.org/10.5772/intechopen.71163

Agbonifo P (2016) Oil spills injustices in the Niger Delta region: reflections on oil industry failure in relation to the United Nations Environment Programme (UNEP) report. International Journal of Petroleum and Gas Exploration Management 2(1):26-37

Agency for Toxic Substances and Disease Registry (ATSDR) (1995) Toxicological profile for polycyclic aromatic hydrocarbons. Atlanta, USA: US Department of Health and Human Services, Public Health Service, Agency for Toxic Substances and Disease Registry

Amnesty International (2018) Niger Delta oil spill decoders. https://www.amnesty.org/en/latest/news/2018/03/niger-delta-

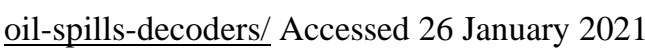

Ana GREE, Sridhar MKC, Emerole GO (2009) A comparative assessment of soil pollution by polycyclic aromatic hydrocarbons in two Niger Delta communities, Nigeria. African Journal of Pure and Applied Chemistry 3(3):031041

Andersson JT, Achten C (2015a) Time to say goodbye to the 16 EPA PAHs? Toward an up-to-date use of PACs for environmental purposes. Polycyclic Aromatic Compounds 35(2-4):330-354. https://doi.org/10.1080/10406638.2014.991042

Andersson JT, Achten C (2015b) A critical look at the 16 EPA PAHs. Polycyclic Aromatic Compounds 35(2-4): 143-146. https://doi.org/10.1080/10406638.2015.1005241 
Asagbra MC, Adebayo AS, Anumudu CI, Ugwumba OA, Ugwumba AAA (2015) Polycyclic aromatic hydrocarbons in water, sediment and fish from the Warri River at Ubeji, Niger Delta, Nigeria, African Journal of Aquatic Science 40(2):193-199 https://doi.org/10.2989/16085914.2015.1035223

Biache C, Mansuy-Huault L, Faure P (2014) Impact of oxidation and biodegradation on the most commonly used polycyclic aromatic hydrocarbon (PAH) diagnostic ratios: Implications for the source identifications. Journal of Hazardous Materials, 267: 31-39. https://doi.org/10.1016/j.jhazmat.2013.12.036

Błaszczyk E, Rogula-Kozłowska W, Klejnowski K, Fulara I, Mielżyńska-Švach D (2016) Polycyclic aromatic hydrocarbons bound to outdoor and indoor airborne particles (PM2.5) and their mutagenicity and carcinogenicity in Silesian kindergartens, Poland. Air Quality, Atmosphere and Health 10:389-400. https://doi.org/10.1007/s11869-016-0457-5

Chen C, Xia Z, Wu M, Zhang Q, Wang T, Wang L, Yang H (2017) Concentrations, source identification, and lung cancer risk associated with springtime pm 2.5-bound polycyclic aromatic hydrocarbons (PAHs) in Nanjing, China. Arch Environ Contam Toxicol 73:391-400 https://doi.org/10.1007/s00244-017-0435-4

Davies OA, Abolude DS (2016) Polycyclic aromatic hydrocarbons (PAHs) of surface water from Oburun Lake, Niger Delta, Nigeria. App. Sci. Report 13(1):20-24. https://doi.org/10.15192/PSCP.ASR.2016.13.1.2024

Dosunmu MI, Oyo-Ita IO, Oyo-Ita OE (2016) Risk assessment of human exposure to polycyclic aromatic hydrocarbons via shrimp (Macrobrachium felicinum) consumption along the Imo River catchments, SE Nigeria. Environ Geochem Health 38:1333-1345. https://doi.org/10.1007/s10653-016-9799-z

Effiong IA, Bassey FI, Iwegbue CMA, Ekpa OD, Williams SA, Oguntunde FC, Osabor VN, Martincigh BS (2016) Polycyclic aromatic hydrocarbons in three commercially available fish species from the Bonny and Cross River estuaries in the Niger Delta, Nigeria. Environ Monit Assess 188:508. https://doi.org/10.1007/s10661-016-5479-9

Ekanem A, Osabor VN, Ekpo B (2019) Polycyclic aromatic hydrocarbons (PAHs) contamination of soils and water around automobile repair workshops in Eket metropolis, Akwa Ibom State, Nigeria. SN Applied Sciences 1(447). https://doi.org/10.1007/s42452-019-0397-4

Ekpete, OA, Edori OS, Iyama W (2019) Concentrations of polycyclic aromatic hydrocarbons from selected dumpsites within Port Harcourt Metropolis, Rivers State, Niger Delta, Nigeria. Int J Environ Sci Nat Res 21(4):556066. https://doi.org/10.19080/IJESNR.2019.21.556066 
Ekpo BO, Oyo-Ita OE, Oros DR, Simoneit BRT (2011) Distributions and sources of polycyclic aromatic hydrocarbons in surface sediments from the Cross River estuary, S.E. Niger Delta, Nigeria. Environ Monit Assess 184:1037-1047. https://doi.org/10.1007/s10661-011-2019-5

Emoyan OO (2020) Quantification and cancer risk evaluation of polycyclic aromatic hydrocarbons in soil around selected telecom masts in Delta state Nigeria. Egypt. J. Chem 63(2):433-448 https://doi.org/10.21608/ejchem.2019.17620.2081

Emoyan OO, Akporhonor EE, Akpoborie IA (2008a) Environmental risk assessment of River Ijana, Ekpan, Delta State.

Nig, J. Chem. Spec. Bioavail 20:23-32

Emoyan OO, Akpoborie IA, Akporhonor EE (2008b) The oil and gas industry and the Niger Delta: Implications for the Environment. J. Appl. Sci. Environ. Mgt. 12:29 -37

Emoyan OO, Onocha EO, Tesi GO (2020) Concentration assessment and source evaluation of 16 priority polycyclic aromatic hydrocarbons in soils from selected vehicle-parks in southern Nigeria. Scientific African 7, e00296. https://doi.org/10.1016/j.sciaf.2020.e00296

European Commission (2006) Commission regulation (EC) No. 1881/2006 setting maximum levels for certain contaminants in foodstuffs. LexUriServ.do (europa.eu) Accessed 30 January 2021

European Commission (EC) (2013) Directive 2013/39/EU of the European Parliament and of the council. https://eurlex.europa.eu/legal-content/EN/ALL/?uri=CELEX:32013L0039\#ntr7-L_2013226EN.01001202-E0007 Accessed 30 January 2021

European Food Safety Authority (2008) Scientific opinion of the panel on contaminants in the food chain on a request from the European Commission on polycyclic aromatic hydrocarbons in food. The EFSA Journal 724:1-114

Faria J (2020) Main oil producing countries in Africa 2019. https://www.statista.com/statistics/1178514/main-oilproducing-countries-in-africa/ Accessed 27 January 2021

Federal Soil Protection and Contaminated Sites Ordinance (FSPCSO) (1998) Act on protection against harmful changes to soil and on rehabilitation of contaminated sites. https://germanlawarchive.iuscomp.org/?p=322\#8 Accessed 30 January 2021

German Federal Environment Agency (2012) Polycyclic aromatic hydrocarbons: Harmful to the environment! Toxic! Inevitable? https://www.umweltbundesamt.de 
Hussar E, Richards S, Lin Z-Q, Dixon RP, Johnson KA (2013) Human health risk assessment of 16 priority polycyclic aromatic hydrocarbons in soils of Chattanooga, Tennessee, USA. Water Air Soil Pollut 223(9):5535-5548. https://doi.org/10.1007/s11270-012-1265-7

Igbiri S, Udowelle NA, Ekhator OC, Asomugha N, Igweze ZN, Orisakwe OE (2017) Polycyclic aromatic hydrocarbons in edible mushrooms from Niger Delta, Nigeria: Carcinogenic and non-carcinogenic health risk assessment. Asian Pac J Cancer Prev 18 (2):437-447. https://doi.org/10.22034/APJCP.2017.18.2.437

Ihunwo O, Bonnail E (2019) Distribution of polycyclic aromatic hydrocarbons in Woji Creek, in the Niger Delta. Environ. Res. Commun 1:125001. https://doi.org/10.1088/2515-7620/ab50f2

Ihuoma, NG, Tamuno-boma O, Umanu GC, Amabinba GD, Erekedoumene F (2020) Comparative study on heavy metals and hydrocarbons accumulation in cassava tubers harvested from four different locations in Rivers State, Nigeria. International Journal of Ecotoxicology and Ecobiology 5(2):23-28. https://doi.org/10.11648/j.ijee.20200502.12

Ikue GS, Monanu MO, Onuah CL (2016) Bioaccumulation of polycyclic aromatic hydrocarbons in tissues (gills and muscles) of (catfish) chrysichthys nigrodidatatus from crude oil polluted water of Ogoniland, River State, Nigeria. Journal of Applied Life Sciences International 6(3):1-6. https://doi.org/10.9734/JALSI/2016/27248

Inam E, Etuk I, Offiong NA, Kim K-W, Kang SW, Essien J (2018) Distribution and ecological risks of polycyclic aromatic hydrocarbons (PAHs) in sediments of different tropical water ecosystems in Niger Delta, Nigeria. Environmental Earth Sciences 77:216. https://doi.org/10.1007/s12665-018-7396-4

Inam E, Offiong N-A, Essien J, Kang S, KangS-Y, Antia B (2015) Polycyclic aromatic hydrocarbons loads and potential risks in freshwater ecosystem of the Ikpa River Basin, Niger Delta-Nigeria. Environ Monit Assess 188:49. https://doi.org/10.1007/s10661-015-5038-9

Inengite AK, Osuji L (2010) Evaluation of polycyclic aromatic hydrocarbons in sediment of Kolo Creek in the Niger Delta. International Journal of Applied Environmental Sciences 5(1):127-143

Iniaghe P, Tesi G, Iniaghe P (2013) Environmental degradation and sustainable development in Nigeria's Niger Delta Region. Journal of Sustainable Development in Africa, 15(1):1-5.

Inoni OE, Omotor DG, Adun FN (2006) The effect of oil spillage on crop yield and farm income in Delta State, Nigeria. Journal of Central European Agriculture, 7(1):41-48. https://doi.org/10.5513/jcea.v7i1.353 
Ite AE, Harry TA, Obadimu CO, Asuaiko ER, Inim IJ (2018) Petroleum hydrocarbons contamination of surface water and groundwater in the Niger Delta Region of Nigeria. Journal of Environment Pollution and Human Health 6(2):5161. https://doi.org/10.12691/jephh-6-2-2

Ite AE, Ibok UJ (2013) Gas flaring and venting associated with petroleum exploration and production in the Nigeria's Niger Delta. American Journal of Environmental Protection 1(4):70-77. https://doi.org/10.12691/env-1-4-1

Ite AE, Ibok UJ, Ite MU, Petters SW (2013) Petroleum exploration and production: past and present environmental issues in the Nigeria's Niger Delta. American Journal of Environmental Protection 1(4):78-90. https://doi.org/10.12691/env-1-4-2

Iwegbue CMA, Obi G (2016) Distribution, sources, and health risk assessment of polycyclic aromatic hydrocarbons in dust from urban environment in the Niger Delta, Nigeria. Human and Ecological Risk Assessment: An International Journal 22(3):623-638. https://doi.org/10.1080/10807039.2015.1100157

Iwegbue CMA, Obi G, Aganbi E, Ogala JE, Omo-Irabor OO, Martincigh BS (2016) Concentrations and health risk assessment of polycyclic aromatic hydrocarbons in soils of an urban environment in the Niger Delta, Nigeria. Toxicol. Environ. Health. Sci 8(3):221-233. https://doi.org/10.1007/s13530-016-0279-8

Mekonnen KN, Chandravanshi BS, Redi-Abshiro M, Ambushe AA, McCrindle RI, Moyo S (2015) Distribution of polycyclic aromatic hydrocarbons in sediments of Akaki River, Lake Awassa, and Lake Ziway, Ethiopia. Environ Monit Assess 187:474. https://doi.org/10.1007/s10661-015-4669-1

Moher D, Liberati A, Tetzlaff J, Altman DG, PRISMA Group (2009) Preferred reporting items for systematic reviews and meta-analyses: the PRISMA statement. J Clin Epidemiol 62:1006-1012

Nduka JK, Anyakora C, Obi E, Obumselu FO, Ezenwa JE, Ngozi-Olehi LC (2013) Polyaromatic hydrocarbons (PAHs) and inorganic chemical contaminants at refuse dumpsites in Awka, South Eastern Nigeria: A public health implication. Journal of Scientific Research \& Reports 2(1):173-189

Nganje TN, Edet AE, Ibok UJ, Ukpabio EJ, Ibe KA, Neji P (2011) Polycyclic aromatic hydrocarbons in surface water and soil in the vicinity of fuel-oil spillage from a tank farm distribution facility, Esuk Utan, Calabar Municipality, Nigeria. Environ Earth Sci 67:81-90. https://doi.org/10.1007/s12665-011-1481-2 
Nganje TN, Neji PA, Ibe KA, Adamu CI, Edet A (2014) Fate, distribution and sources of polycyclic aromatic hydrocarbons (PAHs) in contaminated soils in parts of Calabar Metropolis, South Eastern Nigeria. J. Appl. Sci. Environ. Manage 18(2):309-316. https://doi.org/10.4314/jasem.v18i2.23

Nriagu J, Udofia EA, Ekong I, Ebuk G (2016) Health risks associated with oil pollution in the Niger Delta, Nigeria. 1-23. Int. J. Environ. Res. Public Health 13:346. https://doi.org/10.3390/ijerph13030346

Nwaichi EO, Chuku LC, Ighoavwogan E (2016) Polycyclic aromatic hydrocarbons and selected heavy metals in some oil polluted sites in Delta State Nigeria. Journal of Environmental Protection 7:1389-1410. https://doi.org/10.4236/jep.2016.710120

Nwankwoala HO, Nwanosike AA, Ibrahim HA (2020) Risk evaluation and modelling of soils contaminated with polycyclic aromatic hydrocarbons (PAHs) in parts of Bonny Island, Niger Delta, Nigeria. Ann Civil Environ Eng 4:015-026. https://doi.org/10.29328/journal.acee.1001021

Nwineewii JD, Marcus AC (2015) Polycyclic aromatic hydrocarbons (PAHs) in surface water and their toxicological effects in some creeks of south-east Rivers State (Niger Delta) Nigeria. IOSR Journal of Environmental Science, Toxicology and Food Technology 9(12):27-30

Nyarko E, Botwe BO, Klubi E (2011) Polycyclic aromatic hydrocarbons (PAHs) levels in two commercially important fish species from the coastal waters of Ghana and their carcinogenic health risks. West African Journal of Applied Ecology 19(1):53-66

Obida CB, Blackburn GA, Whyatt JD, Semple KT (2018) Quantifying the exposure of humans and the environment to oil pollution in the Niger Delta using advanced geostatistical techniques. Environment International 111:32-42. https://doi.org/10.1016/j.envint.2017.11.009

Obinaju BE, Graf C, Halsall C, Martin FL (2015) Linking biochemical perturbations in tissues of the African catfish to the presence of polycyclic aromatic hydrocarbons in Ovia River, Niger Delta region. Environmental Pollution 201:42-49. https://doi.org/10.1016/j.envpol.2015.02.031

Obiri S, Cobbina SJ, Armah FA, Naangmenyele Z (2011) Quantification and characterization of vehicle-based polycyclic aromatic hydrocarbons (PAHs) in street dust from the Tamale metropolis, Ghana. Environ Sci Pollut Res 18:1166-1173. https://doi.org/10.1007/s11356-011-0465-9 
Ofori SA, Cobbina SJ, Doke DA (2020a) The occurrence and levels of polycyclic aromatic hydrocarbons (PAHs) in African environments - a systematic review. Environ Sci Pollut Res 27: 32389-32431. https://doi.org/10.1007/s11356$\underline{020-09428-2}$

Ofori SA, Cobbina SJ, Imoro AZ (2020b) PAH quantification and estimated carcinogenic risks at selected fuel stations in Tamale Metropolis, Ghana. Ghana Journal of Science 61(1): 60-72. https://dx.doi.org/10.4314/gjs.v61i1.5

Ogoko EC (2014) Evaluation of polycyclic aromatic hydrocarbons, total petroleum hydrocarbons and some heavy metals in soils of NNPC oil depot Aba Metropolis, Abia State, Nigeria. IOSR Journal of Environmental Science, Toxicology and Food Technology 8(5):21-27

Olajire AA, Altenburger R, Eberhard K, Brack W (2005) Chemical and ecotoxicological assessment of polycyclic aromatic hydrocarbon — contaminated sediments of the Niger Delta, Southern Nigeria. Science of the Total Environment 340:123 - 136, 123-136. https://doi.org/10.1016/j.scitotenv.2004.08.014

Olawoyin R, Grayson RL, Okareh OT (2012) Eco-toxicological and epidemiological assessment of human exposure to polycyclic aromatic hydrocarbons in the Niger Delta, Nigeria. Toxicol. Environ. Health. Sci 4(3):173-185. https://doi.org/10.1007/s13530-012-0133-6

Orgi OR, Asuquo FE, Ibok UJ (2006) Distribution and sources of polyaromatic hydrocarbons (PAHs) in surface sediments of Great Kwa River, Nigeria. Bull. Environ. Contam. Toxicol 77:868-873. https://doi.org/10.1007/s00128-006$\underline{1223-4}$

Osuagwu ES, Olaifa E (2018) Effects of oil spills on fish production in the Niger Delta. PLoS ONE 13(10): e0205114. https://doi.org/10.1371/journal.pone.0205114

Osuji LC, Ilechukwu IP, Onyema MO (2012) Distribution and sources of aliphatic hydrocarbons (AHCs) and polycyclic aromatic hydrocarbons (PAHs) within the vicinity of a hot mix asphalt (HMA) plant in Port Harcourt, Nigeria. International Journal of Environmental Sciences 3(1):697-706. https://doi.org/10.6088/ijes.2012030131068

Owhoeke E, Horsfall MJ, Osu CI (2020) Source tracking and carcinogenic risk of polycyclic aromatic hydrocarbons in contaminated farmlands from Egi Niger Delta, Nigeria. Journal of Drug Design and Medicinal Chemistry 5(4):61 66. https://doi.org/10.11648/j.jddmc.20190504.12

Oyo-Ita OE, Offem JO, Ekpo BO, Adie PA (2012) Anthropogenic PAHs in mangrove sediments of the Calabar River, SE Niger Delta, Nigeria. Applied Geochemistry 28:212-219. https://doi.org/10.1016/j.apgeochem.2012.09.011 
Oyo-ita OE, Oyo-ita IO, Ugim SU (2011) Sources and distribution of polycyclic aromatic hydrocarbons in post flooded soil near Afam power. Journal of Soil Science and Environmental Management 2(11):329-340

Russell AG (2013) Combustion emissions. In: Straif K, Cohen A, Samet J (ed). Air Pollution and Cancer. IARC Scientific Publication No 161, WHO Press, World Health Organization, Switzerland, pp 37-47

Safo-Adu G, Ofosu FG, Carboo D, Serfor-Armah Y (2014) Health risk assessment of exposure to particulate polycyclic aromatic hydrocarbons at a tollbooth on a major highway. Am. J. Sci. Ind. Res 5(4):110-119

Sojinu OSS, Wang JZ, Sonibare OO, Zeng EY (2010) Polycyclic aromatic hydrocarbons in sediments and soils from oil exploration areas of the Niger Delta, Nigeria. Journal of Hazardous Materials 174:641-647. https://doi.org/10.1016/j.jhazmat.2009.09.099

Stogiannidis E, Laane R (2015) In: Whitacre D. (eds) Reviews of environmental contamination and toxicology. Reviews of environmental contamination and toxicology (continuation of residue reviews), vol 234. Springer, Cham. https://doi.org/10.1007/978-3-319-10638-0_2

Tongo I, Ezemonye L, Akpeh K (2017) Distribution, characterization, and human health risk assessment of polycyclic aromatic hydrocarbons (PAHs) in Ovia River, Southern Nigeria. Environ Monit Assess 189:247. https://doi.org/10.1007/s10661-017-5931-5

Ugochukwu UC, Ochonogor A, Jidere CM, Agu C, Nkoloagu F, Ewoh J, Okwu-delunzu VU (2018) Exposure risks to polycyclic aromatic hydrocarbons by humans and livestock (cattle) due to hydrocarbon spill from petroleum products in Niger-delta wetland. Environment International 115:38-47. https://doi.org/10.1016/j.envint.2018.03.010

United Nations Environment Programme (UNEP) (2011) Environmental assessment of Ogoni land. No. DEP/1337/GE 262.

United States Environmental Protection Agency (USEPA) (1991) Risk assessment guidance for superfund. Volume I — human health evaluation manual (Part B, Development of Risk-based Preliminary Remediation Goals) EPA/540/R-92/003. Office of Research and Development, Washington, DC 20460

United States Environmental Protection Agency (USEPA) (2009) National Primary Drinking Water Regulation Table. https://www.epa.gov/ground-water-and-drinking-water/national-primary-drinking-water-regulation-table Accessed 30 January 2021 
United States Environmental Protection Agency (USEPA) (2014) Toxic and priority pollutants under the Clean Water Act. https://19january2017snapshot.epa.gov/eg/toxic-and-priority-pollutants-under-clean-water-act_html\#priority Accessed 30 January 2021

Uzoekwe SA, Ikpesu TO (2020) Concentration distribution and ecological risk assessment of polycyclic aromatic hydrocarbon in Kolo Creek Niger-Delta Nigeria. Scientific Review 6(7):62-70. https://doi.org/10.32861/sr.67.62.70

Wang, CH, Wu SH, Zhou SL, Shi YX, Song J (2017) Characteristics and source identification of polycyclic aromatic hydrocarbons (PAHs) in urban soils: A Review. Pedosphere 27(1):17-26. https://doi.org/10.1016/S1002$\underline{0160(17) 60293-5}$

Wells G, Shea B, O’Connell D, Peterson J, Welch V, Losos M, Tugwell P (2009) The Newcastle-Ottawa Scale (NOS) for assessing the quality of nonrandomized studies in meta-analyses. http://www.ohri.ca/programs/clinical_epidemiology/oxford.htm. Accessed 20 September 2020

Zhang CC (2006) Fundamentals of Environmental Sampling and Analysis. John Wiley \& Sons, Inc., New Jersey https://doi.org/10.1002/0470120681 
2 Table 1 Quality assessments of selected studies using Newcastle-Ottawa Scale

\begin{tabular}{|c|c|c|c|c|c|c|c|c|c|}
\hline $\begin{array}{l}\text { Authors } \\
\text { (year) }\end{array}$ & $\begin{array}{l}\text { Period of } \\
\text { sampling } \\
\text { indicated }\end{array}$ & $\begin{array}{l}\text { Control } \\
\text { samples } \\
\text { included }\end{array}$ & $\begin{array}{l}\text { Sampling } \\
\text { technique } \\
\text { indicated }\end{array}$ & $\begin{array}{l}\text { Clean-up process } \\
\text { conducted }\end{array}$ & $\begin{array}{l}\text { QA/QC } \\
\text { conducted }\end{array}$ & $\begin{array}{l}\text { All } \\
\text { objectives } \\
\text { achieved }\end{array}$ & $\begin{array}{l}\text { Report } \\
\text { on PAH } \\
\text { sources }\end{array}$ & $\begin{array}{l}\text { Report on } \\
\text { mean PAH } \\
\text { levels }\end{array}$ & $\begin{array}{l}\text { Overall } \\
\text { quality } \\
\text { score }\end{array}$ \\
\hline $\begin{array}{l}\text { Olajire et al. } \\
(2005)\end{array}$ & No & No & Yes & Yes & No & Yes & Yes & Yes & $5 / 8$ \\
\hline $\begin{array}{l}\text { Orgi et al. } \\
(2006)\end{array}$ & No & No & No & Yes & No & Yes & No & No & $2 / 8$ \\
\hline $\begin{array}{l}\text { Inengite et } \\
\text { al. (2010) }\end{array}$ & Yes & No & No & Yes & Yes & Yes & Yes & No & $5 / 8$ \\
\hline $\begin{array}{l}\text { Sojinu et al. } \\
(2010)\end{array}$ & Yes & No & Yes & Yes & Yes & Yes & Yes & Yes & $7 / 8$ \\
\hline $\begin{array}{l}\text { Ekpo et al. } \\
\text { (2011) }\end{array}$ & No & No & No & Yes & Yes & Yes & Yes & Yes & $5 / 8$ \\
\hline $\begin{array}{l}\text { Oyo-Ita et } \\
\text { al. (2012) }\end{array}$ & No & No & No & No & Yes & Yes & Yes & Yes & $4 / 8$ \\
\hline $\begin{array}{l}\text { Asagbra et } \\
\text { al. (2015) }\end{array}$ & Yes & Yes & No & Yes & Yes & Yes & Yes & Yes & $7 / 8$ \\
\hline $\begin{array}{l}\text { Inam et al. } \\
(2015)\end{array}$ & Yes & No & Yes & No & Yes & Yes & No & Yes & $5 / 8$ \\
\hline $\begin{array}{l}\text { Nwineewii } \\
\text { and Marcus } \\
(2015)\end{array}$ & No & No & No & Yes & No & Yes & No & No & $2 / 8$ \\
\hline $\begin{array}{l}\text { Dosunmu et } \\
\text { al. (2016) }\end{array}$ & Yes & No & Yes & Yes & Yes & Yes & No & Yes & $6 / 8$ \\
\hline $\begin{array}{l}\text { Davies and } \\
\text { Abolude } \\
\text { (2016) }\end{array}$ & Yes & No & No & No & No & Yes & Yes & Yes & $4 / 8$ \\
\hline $\begin{array}{l}\text { Obinaju et } \\
\text { al. (2015) }\end{array}$ & No & No & No & Yes & Yes & Yes & No & No & $3 / 8$ \\
\hline $\begin{array}{l}\text { Ikue et al. } \\
(2016)\end{array}$ & No & No & No & Yes & No & Yes & No & Yes & $3 / 8$ \\
\hline $\begin{array}{l}\text { Tongo et al. } \\
\text { (2017) }\end{array}$ & Yes & No & Yes & Yes & Yes & Yes & Yes & Yes & $7 / 8$ \\
\hline
\end{tabular}




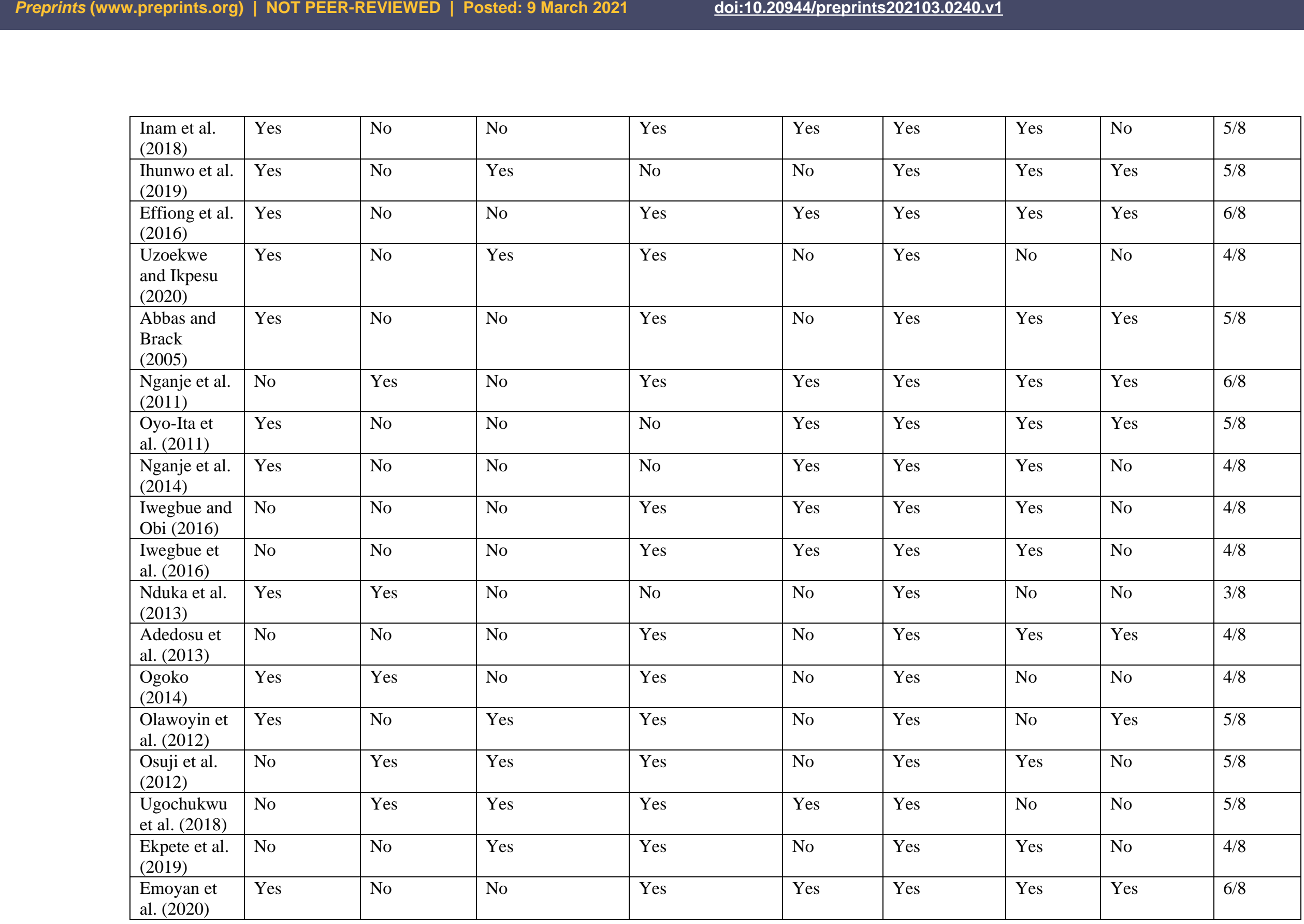




\begin{tabular}{|l|l|l|l|l|l|l|l|l|l|}
\hline $\begin{array}{l}\text { Emoyan } \\
(2020)\end{array}$ & No & Yes & No & Yes & Yes & Yes & Yes & Yes & Y/8 \\
\hline $\begin{array}{l}\text { Nwankwoala } \\
\text { et al. (2020) }\end{array}$ & No & Yes & Yes & Yes & Yes & Yes & Yes \\
\hline $\begin{array}{l}\text { Owhoeke et } \\
\text { al. (2020) }\end{array}$ & No & Yes & No & No & No & Yes & Yes \\
\hline $\begin{array}{l}\text { Nwaichi et } \\
\text { al. (2016) }\end{array}$ & No & Yes & Yes & Yes & Yes & Yes & No & Yes \\
\hline $\begin{array}{l}\text { Igbiri et al. } \\
(2017)\end{array}$ & Yes & No & No & Yes & Yes & Yes & No & No \\
\hline
\end{tabular}

5 Table 2 PAHs in aquatic environments

\begin{tabular}{|c|c|c|c|c|c|c|c|}
\hline $\begin{array}{l}\text { Sample } \\
\text { category }\end{array}$ & Reference & $\begin{array}{l}\text { Type of } \\
\text { sample/sampling } \\
\text { area }\end{array}$ & $\begin{array}{l}\text { Polluting } \\
\text { activity }\end{array}$ & Extraction method & $\begin{array}{l}\text { Analytical } \\
\text { technique }\end{array}$ & $\begin{array}{l}\text { PAH } \\
\text { concentration }\end{array}$ & $\begin{array}{l}\text { Number of PAHs and } \\
\text { potential sources }\end{array}$ \\
\hline \multirow[t]{4}{*}{$\begin{array}{l}\text { Aquatic } \\
\text { environments }\end{array}$} & $\begin{array}{l}\text { Olajire et al. } \\
(2005)\end{array}$ & Sediments & $\begin{array}{l}\text { Incidents of oil } \\
\text { spill }\end{array}$ & $\begin{array}{l}\text { Soxhlet extraction with } \\
\text { Dichloromethane (DCM) }\end{array}$ & GC-MS & $0.02-0.072 \mathrm{mg} / \mathrm{kg}$ & $\begin{array}{l}16 \text { PAHs of petrogenic } \\
\text { sources from six rivers } \\
\text { of the Niger Delta }\end{array}$ \\
\hline & $\begin{array}{l}\text { Orgi et al. } \\
(2006)\end{array}$ & Sediments & $\begin{array}{l}\text { Effluent } \\
\text { discharge from } \\
\text { agricultural and } \\
\text { industrial } \\
\text { activities, } \\
\text { incidents of oil } \\
\text { spill, and } \\
\text { shipping } \\
\text { activities }\end{array}$ & $\begin{array}{l}\text { Soxhlet extraction with a } \\
\text { mixture of DCM and } \\
\text { methanol }(60: 40, v / v)\end{array}$ & GC-FID & $2.38-5.18 \mathrm{mg} / \mathrm{kg}$ & $\begin{array}{l}16 \text { PAHs from the } \\
\text { Great Kwa River }\end{array}$ \\
\hline & \multirow[t]{2}{*}{$\begin{array}{l}\text { Inengite et } \\
\text { al. (2010) }\end{array}$} & $\begin{array}{l}\text { Sediments (dry } \\
\text { season) }\end{array}$ & \multirow[t]{2}{*}{ Gas flaring } & \multirow[t]{2}{*}{$\begin{array}{l}\text { Filtration method with } 10 \\
\text { mL of Pentane }\end{array}$} & \multirow[t]{2}{*}{ GC-FID } & $0-0.350 \mathrm{mg} / \mathrm{kg}$ & \multirow{2}{*}{$\begin{array}{l}16 \text { PAHs of pyrogenic } \\
\text { sources from the Kolo } \\
\text { Creek }\end{array}$} \\
\hline & & $\begin{array}{l}\text { Sediments (rainy } \\
\text { season) }\end{array}$ & & & & $0.22-0.470 \mathrm{mg} / \mathrm{kg}$ & \\
\hline
\end{tabular}




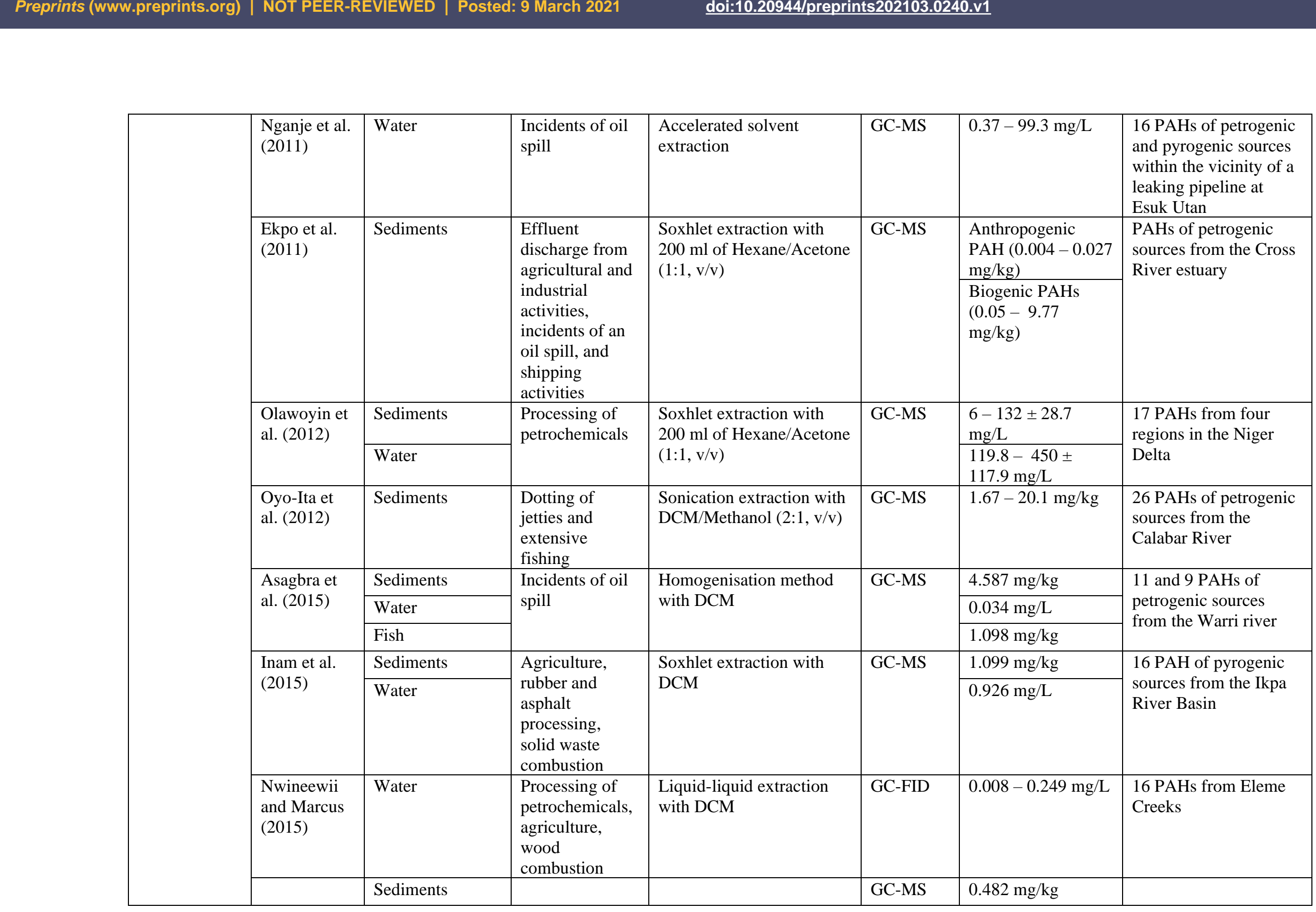




\begin{tabular}{|c|c|c|c|c|c|c|}
\hline $\begin{array}{l}\text { Dosunmu et } \\
\text { al. (2016) }\end{array}$ & Shrimps & $\begin{array}{l}\text { Processing of } \\
\text { fertilizers and } \\
\text { petrochemicals }\end{array}$ & $\begin{array}{l}\text { Sonication extraction with } \\
15 \mathrm{~mL} \text { of } \\
\text { Acetone/n-Hexane (1:1, } \\
\mathrm{v} / \mathrm{v})\end{array}$ & & $0.460 \pm 0.33 \mathrm{mg} / \mathrm{kg}$ & $\begin{array}{l}16 \text { PAHs from the Imo } \\
\text { river }\end{array}$ \\
\hline $\begin{array}{l}\text { Davies and } \\
\text { Abolude } \\
\text { (2016) }\end{array}$ & Water & $\begin{array}{l}\text { OEE operations, } \\
\text { effluent } \\
\text { discharge }\end{array}$ & Not defined & $\begin{array}{l}\text { Not } \\
\text { defined }\end{array}$ & $0-0.018 \mathrm{mg} / \mathrm{L}$ & \begin{tabular}{|l}
16 PAHs of \\
anthropogenic or \\
natural sources from \\
the Oburun lake \\
\end{tabular} \\
\hline $\begin{array}{l}\text { Obinaju et } \\
\text { al. (2015) } \\
\end{array}$ & Water & $\begin{array}{l}\text { Incidents of oil } \\
\text { spill }\end{array}$ & $\begin{array}{l}\text { Solid-phase extraction } \\
\text { with } 10 \mathrm{ml} \text { of DCM }\end{array}$ & GC-MS & $0-1.055 \mathrm{mg} / \mathrm{L}$ & $\begin{array}{l}16 \text { PAHs from the Ovia } \\
\text { river }\end{array}$ \\
\hline \multirow[t]{4}{*}{$\begin{array}{l}\text { Ikue et al. } \\
\text { (2016) }\end{array}$} & $\begin{array}{l}\text { Fish muscle } \\
\text { (Bodo city) }\end{array}$ & \multirow[t]{4}{*}{$\begin{array}{l}\text { Incidents of oil } \\
\text { spills }\end{array}$} & \multirow[t]{4}{*}{$\begin{array}{l}\text { Filtration method with } 10 \\
\text { ml of DCM }\end{array}$} & \multirow[t]{4}{*}{ GC-FID } & $0.009 \mathrm{mg} / \mathrm{kg}$ & \multirow{4}{*}{$\begin{array}{l}17 \text { PAHs from landing } \\
\text { beaches of Bodo City } \\
\text { and Kaa waterside }\end{array}$} \\
\hline & $\begin{array}{l}\text { Fish muscle } \\
\text { (Kaa) }\end{array}$ & & & & $0.005 \mathrm{mg} / \mathrm{kg}$ & \\
\hline & $\begin{array}{l}\text { Fish gills (Bodo } \\
\text { city) }\end{array}$ & & & & $0.181 \mathrm{mg} / \mathrm{kg}$ & \\
\hline & Fish gills (Kaa) & & & & $0.006 \mathrm{mg} / \mathrm{kg}$ & \\
\hline \multirow[t]{3}{*}{$\begin{array}{l}\text { Tongo et al. } \\
(2017)\end{array}$} & Sediments & \multirow[t]{3}{*}{$\begin{array}{l}\text { Incidents of oil } \\
\text { spill }\end{array}$} & $\begin{array}{l}\text { Sonication method with } \\
\text { mixture of DCM and n- } \\
\text { Hexane }(2: 3, v / v)\end{array}$ & \multirow[t]{3}{*}{ GC-MS } & $\begin{array}{l}0.005-0.573 \\
\mathrm{mg} / \mathrm{kg}\end{array}$ & \multirow[t]{3}{*}{$\begin{array}{l}17 \text { PAHs of pyrogenic } \\
\text { and petrogenic sources } \\
\text { from the Ovia River }\end{array}$} \\
\hline & Water & & 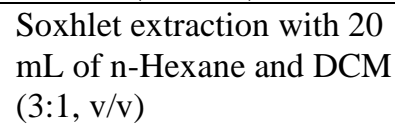 & & $0.002-0.025 \mathrm{mg} / \mathrm{L}$ & \\
\hline & Fish & & $\begin{array}{l}\text { Soxhlet extraction with } \\
\text { mixture of DCM and n- } \\
\text { Hexane }\end{array}$ & & $\begin{array}{l}0.010-0.914 \\
\mathrm{mg} / \mathrm{kg}\end{array}$ & \\
\hline \multirow[t]{3}{*}{$\begin{array}{l}\text { Inam et al. } \\
(2018)\end{array}$} & $\begin{array}{l}\text { Sediments (Ikpa } \\
\text { River Basin) }\end{array}$ & \multirow{3}{*}{$\begin{array}{l}\text { Agriculture, } \\
\text { rubber and } \\
\text { asphalt } \\
\text { processing, } \\
\text { solid waste } \\
\text { combustion }\end{array}$} & \multirow{3}{*}{$\begin{array}{l}\text { Soxhlet extraction with } \\
\text { DCM/n-Hexane as solvent } \\
(7: 3, v / v)\end{array}$} & \multirow[t]{3}{*}{ GC-MS } & $1.055 \mathrm{mg} / \mathrm{kg}$ & \multirow{3}{*}{$\begin{array}{l}16 \text { PAHs from the Ikpa } \\
\text { River Basin, the } \\
\text { Eniong River, and the } \\
\text { Douglas/Stubbs Creek }\end{array}$} \\
\hline & $\begin{array}{l}\text { Sediments } \\
\text { (Eniong River) }\end{array}$ & & & & $0.011 \mathrm{mg} / \mathrm{kg}$ & \\
\hline & $\begin{array}{l}\text { Sediments } \\
\text { (Douglas/Stubbs } \\
\text { Creek) }\end{array}$ & & & & $0.014 \mathrm{mg} / \mathrm{kg}$ & \\
\hline \multirow[t]{2}{*}{$\begin{array}{l}\text { Ihunwo et al. } \\
(2019)\end{array}$} & Sediments & \multirow[t]{2}{*}{$\begin{array}{l}\text { Incidents of oil } \\
\text { spill }\end{array}$} & \multirow[t]{2}{*}{ Not defined } & \multirow[t]{2}{*}{ GC-MS } & $\begin{array}{l}687.93-1821.5 \\
\mathrm{mg} / \mathrm{kg}\end{array}$ & \multirow{2}{*}{$\begin{array}{l}10 \text { and } 15 \text { PAHs of } \\
\text { petrogenic and } \\
\text { pyrogenic sources from } \\
\text { the Woji Creek }\end{array}$} \\
\hline & Water & & & & $\begin{array}{l}6.029-29.257 \\
\mathrm{mg} / \mathrm{kg}\end{array}$ & \\
\hline
\end{tabular}




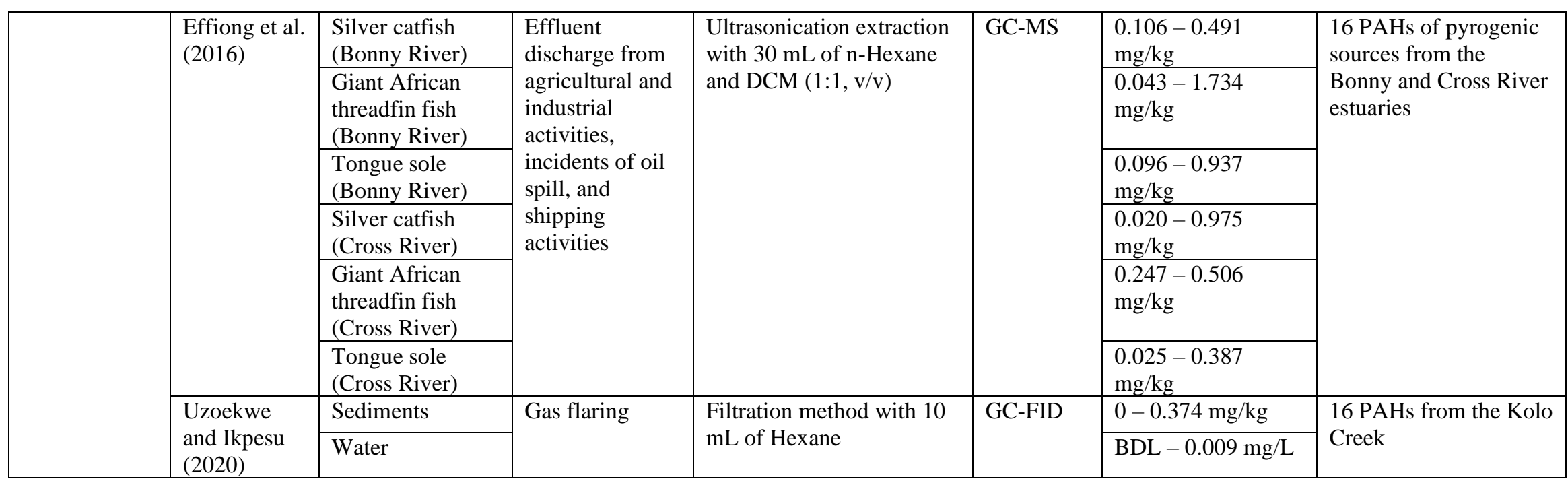

Table 3 PAHs in dust and soil

\begin{tabular}{|c|c|c|c|c|c|c|c|}
\hline $\begin{array}{l}\text { Sample } \\
\text { category }\end{array}$ & Reference & $\begin{array}{l}\text { Type of } \\
\text { sample/sampling } \\
\text { area }\end{array}$ & Polluting activity & Extraction method & $\begin{array}{l}\text { Analytical } \\
\text { technique }\end{array}$ & $\begin{array}{l}\text { PAH } \\
\text { concentration }\end{array}$ & $\begin{array}{l}\text { Number of PAHs and } \\
\text { potential sources }\end{array}$ \\
\hline \multirow[t]{3}{*}{$\begin{array}{l}\text { Dust } \\
\text { and Soil }\end{array}$} & $\begin{array}{l}\text { Abbas and } \\
\text { Brack } \\
(2005)\end{array}$ & Soil & Incidents of oil spill & $\begin{array}{l}\text { Soxhlet extraction with } \\
\text { DCM }\end{array}$ & GC-MS & $\begin{array}{l}0.154-0.750 \\
\mathrm{mg} / \mathrm{kg}\end{array}$ & $\begin{array}{l}16 \text { PAHs of petrogenic } \\
\text { sources from major ports } \\
\text { in the Niger Delta }\end{array}$ \\
\hline & $\begin{array}{l}\text { Sojinu et al. } \\
(2010)\end{array}$ & Soil & OEE operations & $\begin{array}{l}\text { Soxhlet extraction with } \\
200 \mathrm{~mL} \text { of DCM }\end{array}$ & GC-MS & $\begin{array}{l}0.024-0.12 \\
\mathrm{mg} / \mathrm{kg}\end{array}$ & $\begin{array}{l}28 \text { PAHs of pyrogenic } \\
\text { sources from } \\
\text { communities close to oil } \\
\text { installations }\end{array}$ \\
\hline & $\begin{array}{l}\text { Nganje et al. } \\
(2011)\end{array}$ & Soil & $\begin{array}{l}\text { Petroleum handling } \\
\text { facilities, fuel } \\
\text { distributors, vehicle } \\
\text { repairs, small scale } \\
\text { motor mechanics, }\end{array}$ & $\begin{array}{l}\text { Accelerated solvent } \\
\text { extraction with Water, } \\
\text { Acetone, Cyclohexane, } \\
\text { and Toluene }\end{array}$ & GC-MS & $\begin{array}{l}0.016- \\
25.548 \mathrm{mg} / \mathrm{kg}\end{array}$ & $\begin{array}{l}16 \text { PAHs from spill sites } \\
\text { of Esuk Utan community } \\
\text { and environs }\end{array}$ \\
\hline
\end{tabular}




\begin{tabular}{|c|c|c|c|c|c|c|}
\hline & & $\begin{array}{l}\text { vehicle overhaul } \\
\text { services }\end{array}$ & & & & \\
\hline \multirow{2}{*}{$\begin{array}{l}\text { Oyo-Ita et } \\
\text { al. (2011) }\end{array}$} & Soil (forest) & \multirow[t]{2}{*}{$\begin{array}{l}\text { Wood combustion and } \\
\text { power generation }\end{array}$} & \multirow{2}{*}{$\begin{array}{l}\text { Sonication extraction } \\
\text { with DCM/Methanol } \\
(2: 1, \mathrm{v} / \mathrm{v})\end{array}$} & \multirow[t]{2}{*}{ GC-MS } & $\begin{array}{l}0.002-0.005 \\
\mathrm{mg} / \mathrm{kg}\end{array}$ & \multirow{2}{*}{$\begin{array}{l}10 \text { PAHs of petrogenic } \\
\text { sources from polluted } \\
\text { forest land and a point } \\
\text { source in the Niger Delta }\end{array}$} \\
\hline & $\begin{array}{l}\text { Soil (pollution } \\
\text { source) }\end{array}$ & & & & $\begin{array}{l}0.011-0.047 \\
\mathrm{mg} / \mathrm{kg}\end{array}$ & \\
\hline $\begin{array}{l}\text { Nganje et al. } \\
\text { (2014) }\end{array}$ & Soil & Incidents of oil spill & $\begin{array}{l}\text { Accelerated solvent } \\
\text { extraction }\end{array}$ & GC-MS & $\begin{array}{l}4.28-29.77 \\
\mathrm{mg} / \mathrm{kg}\end{array}$ & $\begin{array}{l}16 \text { PAHs of petrogenic } \\
\text { and pyrogenic sources } \\
\text { from two spilt sites in } \\
\text { Calabar Metropolis }\end{array}$ \\
\hline $\begin{array}{l}\text { Iwegbue and } \\
\text { Obi (2016) }\end{array}$ & Dust & Incidents of oil spill & $\begin{array}{l}\text { Ultra-sonication method } \\
\text { with } 50 \mathrm{~mL} \text { of } \\
\text { hexane/DCM }(1: 1, \mathrm{v} / \mathrm{v})\end{array}$ & GC-MS & $\begin{array}{l}165.1-1012 \\
\mathrm{mg} / \mathrm{kg}\end{array}$ & $\begin{array}{l}16 \text { PAHs of pyrogenic } \\
\text { sources from Warri and } \\
\text { its environs }\end{array}$ \\
\hline $\begin{array}{l}\text { Iwegbue et } \\
\text { al. (2016) }\end{array}$ & Soil & Incidents of oil spill & $\begin{array}{l}\text { Accelerated Solvent } \\
\text { Extraction with hexane } \\
\text { and DCM }(1: 1, \mathrm{v} / \mathrm{v})\end{array}$ & GC-MS & $\begin{array}{l}0.188-0.684 \\
\mathrm{mg} / \mathrm{kg}\end{array}$ & $\begin{array}{l}16 \text { PAHs of pyrogenic } \\
\text { sources from Warri and } \\
\text { its environs }\end{array}$ \\
\hline $\begin{array}{l}\text { Nduka et al. } \\
\text { (2013) }\end{array}$ & Soil & Solid waste combustion & $\begin{array}{l}\text { Soxhlet extraction with } \\
100 \mathrm{~mL} \text { of DCM }\end{array}$ & GC-MS & $\begin{array}{l}\mathrm{ND}- \\
2392.06 \\
\mathrm{mg} / \mathrm{kg}\end{array}$ & $\begin{array}{l}16 \text { PAHs from refuse } \\
\text { dumpsites at Awka }\end{array}$ \\
\hline $\begin{array}{l}\text { Adedosu et } \\
\text { al. (2013) }\end{array}$ & Soil & Gas flaring facilities & $\begin{array}{l}\text { Soxhlet extraction with } \\
\text { DCM }\end{array}$ & GC-FID & $\begin{array}{l}0.0074- \\
0.078 \mathrm{mg} / \mathrm{kg}\end{array}$ & $\begin{array}{l}16 \text { PAHs of pyrolytic } \\
\text { sources from gas flaring } \\
\text { sites in Etche and Obio } \\
\text { Akpor LGA }\end{array}$ \\
\hline $\begin{array}{l}\text { Ogoko } \\
\text { (2014) }\end{array}$ & Soil & $\begin{array}{l}\text { Pipeline transport of } \\
\text { petroleum products }\end{array}$ & $\begin{array}{l}\text { Microwave extraction } \\
\text { with } 25 \mathrm{~mL} \text { n-Hexane } \\
\text { and Acetone }(7: 3, \mathrm{v} / \mathrm{v})\end{array}$ & GC-MS & $\begin{array}{l}6.3-7.4 \\
\mathrm{mg} / \mathrm{kg}\end{array}$ & $\begin{array}{l}\text { PAHs from oil depots in } \\
\text { Aba city }\end{array}$ \\
\hline $\begin{array}{l}\text { Olawoyin et } \\
\text { al. (2012) }\end{array}$ & Soil & $\begin{array}{l}\text { Processing of } \\
\text { petrochemicals }\end{array}$ & $\begin{array}{l}\text { Soxhlet extraction with } \\
200 \mathrm{~mL} \text { of } \\
\text { Hexane/Acetone (1:1, } \\
\mathrm{v} / \mathrm{v})\end{array}$ & GC-MS & $\begin{array}{l}297-4080.6 \\
\pm 546.3 \mathrm{mg} / \mathrm{kg}\end{array}$ & $\begin{array}{l}7 \text { PAHs from a petroleum } \\
\text { region }\end{array}$ \\
\hline $\begin{array}{l}\text { Osuji et al. } \\
\text { (2012) }\end{array}$ & Soil & $\begin{array}{l}\text { Production of asphalt in } \\
\text { Hot Mix Asphalt } \\
\text { (HMA) plants }\end{array}$ & $\begin{array}{l}\text { Shake extraction with } \\
10 \mathrm{~mL} \text { of DCM }\end{array}$ & GC-FID & $\begin{array}{l}117.67- \\
2226.44 \\
\mathrm{mg} / \mathrm{kg}\end{array}$ & $\begin{array}{l}16 \text { PAHs of pyrogenic } \\
\text { sources from the vicinity } \\
\text { of a Hot Mix Asphalt } \\
\text { (HMA) plant }\end{array}$ \\
\hline $\begin{array}{l}\text { Ugochukwu } \\
\text { et al. (2018) }\end{array}$ & Soil & Incidents of oil spill & $\begin{array}{l}\text { Agitation extraction } \\
\text { with } 100 \mathrm{~mL} \\
\text { DCM/acetone }(1: 1, \mathrm{v} / \mathrm{v})\end{array}$ & GC-MS & $\begin{array}{l}1.9-461.3 \\
\mathrm{mg} / \mathrm{kg}\end{array}$ & $\begin{array}{l}16 \text { PAHs from oil spill } \\
\text { sites in the Obuaku } \\
\text { wetland }\end{array}$ \\
\hline
\end{tabular}




\begin{tabular}{|c|c|c|c|c|c|c|}
\hline $\begin{array}{l}\text { Ekpete et al. } \\
\text { (2019) }\end{array}$ & Soil & Solid waste combustion & $\begin{array}{l}\text { Soxhlet extraction with } \\
10 \mathrm{~mL} \text { of methanol and } \\
25 \mathrm{~mL} \text { of } \\
\text { DCM }\end{array}$ & GC & $\begin{array}{l}21.987- \\
60.958 \mathrm{mg} / \mathrm{kg}\end{array}$ & $\begin{array}{l}16 \text { PAHs of pyrogenic } \\
\text { sources from three waste } \\
\text { dumpsites in Port } \\
\text { Harcourt }\end{array}$ \\
\hline $\begin{array}{l}\text { Emoyan } \\
(2020)\end{array}$ & Soil & $\begin{array}{l}\text { Incidents of diesel oil } \\
\text { spills and/or emission of } \\
\text { gaseous particles from } \\
\text { telecom masts }\end{array}$ & $\begin{array}{l}\text { Soxhlet extraction with } \\
100 \text { mL Methylene - } \\
\text { Chloride }\end{array}$ & GC-FID & $\begin{array}{l}0.236- \\
10.622 \mathrm{mg} / \mathrm{kg}\end{array}$ & $\begin{array}{l}16 \text { PAHs of pyrogenic } \\
\text { sources from the areas of } \\
\text { some telecom masts }\end{array}$ \\
\hline \multirow[t]{4}{*}{$\begin{array}{l}\text { Emoyan et } \\
\text { al. (2020) }\end{array}$} & $\begin{array}{l}\text { Soil (Topsoil-Dry } \\
\text { season) }\end{array}$ & \multirow[t]{4}{*}{ Vehicular emissions } & \multirow{4}{*}{$\begin{array}{l}\text { Sonication method with } \\
50 \mathrm{~mL} \text { of } \\
\text { hexane/dichloromethane } \\
(\mathrm{DCM})(1: 1, \mathrm{v} / \mathrm{v})\end{array}$} & \multirow[t]{4}{*}{ GC-FID } & $\begin{array}{l}0.664-0.269 \\
\mathrm{mg} / \mathrm{kg}\end{array}$ & \multirow{4}{*}{$\begin{array}{l}16 \text { PAHs of pyrogenic } \\
\text { sources from vehicle } \\
\text { parks }\end{array}$} \\
\hline & $\begin{array}{l}\text { Soil (Subsoil-Dry } \\
\text { season) }\end{array}$ & & & & $\begin{array}{l}212.1 \text { to } 1.343 \\
\mathrm{mg} / \mathrm{kg}\end{array}$ & \\
\hline & $\begin{array}{l}\text { Soil (Topsoil- } \\
\text { Wet season) }\end{array}$ & & & & $\begin{array}{l}0.366-1.066 \\
\mathrm{mg} / \mathrm{kg}\end{array}$ & \\
\hline & $\begin{array}{l}\text { Soil (Subsoil- } \\
\text { Wet season) }\end{array}$ & & & & $\begin{array}{l}0.143- \\
5321.9 \mathrm{mg} / \mathrm{kg}\end{array}$ & \\
\hline $\begin{array}{l}\text { Nwankwoala } \\
\text { et al. }(2020)\end{array}$ & Soil & Incidents of oil spill & $\begin{array}{l}\text { Liquid to liquid } \\
\text { extraction with } 20 \mathrm{~mL} \\
\text { of DCM }\end{array}$ & GC-MS & $\begin{array}{l}0.02-28.49 \\
\mathrm{mg} / \mathrm{kg}\end{array}$ & $\begin{array}{l}\text { 16 PAHs from a spill site } \\
\text { in Bonny Island }\end{array}$ \\
\hline $\begin{array}{l}\text { Owhoeke et } \\
\text { al. }(2020)\end{array}$ & Soil & Incidents of oil spill & Not defined & GC-FID & $\begin{array}{l}354.7 \pm 360.7 \\
-4154 \pm \\
3461 \mathrm{mg} / \mathrm{kg}\end{array}$ & $\begin{array}{l}16 \text { PAHs of pyrogenic } \\
\text { and petrogenic sources } \\
\text { from crude oil } \\
\text { contaminated farmland in } \\
\text { Egi }\end{array}$ \\
\hline
\end{tabular}

11 Table 4 PAHs in crops

\begin{tabular}{|c|c|c|c|c|c|c|c|}
\hline $\begin{array}{l}\text { Sample } \\
\text { category }\end{array}$ & Reference & $\begin{array}{l}\text { Type of } \\
\text { sample/sampling } \\
\text { area }\end{array}$ & Polluting activity & $\begin{array}{l}\text { Extraction } \\
\text { method }\end{array}$ & $\begin{array}{l}\text { Analytical } \\
\text { technique }\end{array}$ & \begin{tabular}{|l} 
PAH \\
concentration
\end{tabular} & $\begin{array}{l}\text { Number of PAHs } \\
\text { and potential } \\
\text { sources }\end{array}$ \\
\hline \multirow[t]{2}{*}{ Crops } & \multirow[t]{2}{*}{$\begin{array}{l}\text { Nwaichi et } \\
\text { al. (2016) }\end{array}$} & $\begin{array}{l}\text { Cassava tubers } \\
\text { (Ekore) }\end{array}$ & \multirow[t]{2}{*}{$\begin{array}{l}\text { Incidents of oil } \\
\text { spill }\end{array}$} & \multirow[t]{2}{*}{$\begin{array}{l}\text { Filtration method } \\
\text { with } 10 \mathrm{~mL} \text { of } \\
\text { DCM }\end{array}$} & \multirow[t]{2}{*}{ GC-FID } & $0.504 \mathrm{mg} / \mathrm{kg}$ & \multirow[t]{2}{*}{$\begin{array}{l}17 \text { PAHs from crude } \\
\text { oil polluted farm } \\
\text { crops in Ughevwughe } \\
\text { community }\end{array}$} \\
\hline & & $\begin{array}{l}\text { African oil bean } \\
\text { (Ekore) }\end{array}$ & & & & $0.447 \mathrm{mg} / \mathrm{kg}$ & \\
\hline
\end{tabular}




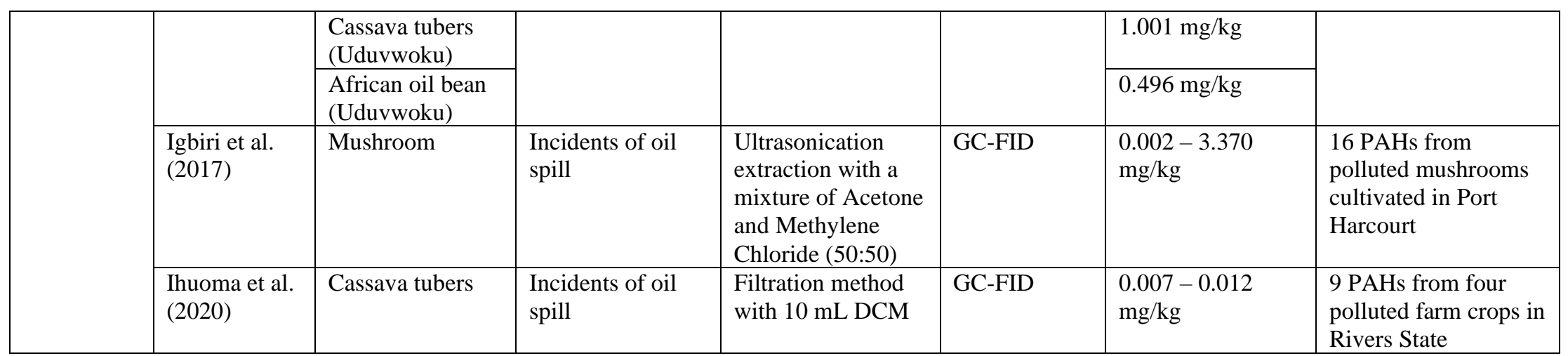

Table 5 Results of human health risk assessment reported by some selected studies

\begin{tabular}{|c|c|c|c|c|c|c|c|c|c|c|c|}
\hline \multirow{3}{*}{$\begin{array}{l}\text { Sample } \\
\text { category }\end{array}$} & \multirow[t]{3}{*}{ Sample } & \multirow{2}{*}{\multicolumn{3}{|c|}{ Hazard Index (HI) }} & \multicolumn{6}{|c|}{ Mean ILCR (mg/kg/day) } & \multirow[t]{3}{*}{ References } \\
\hline & & & & & \multicolumn{3}{|l|}{ Children } & \multicolumn{3}{|l|}{ Adult } & \\
\hline & & Ingestion & Inhalation & Dermal & Ingestion & Inhalation & Dermal & Ingestion & Inhalation & Dermal & \\
\hline \multirow[t]{5}{*}{ Dust and Soil } & Soil & - & - & - & $\begin{array}{l}2.25 \times 10^{-5}- \\
1.90 \times 10^{-3}\end{array}$ & $\begin{array}{l}2.12 \times 10^{-13}- \\
5.70 \times 10^{-12}\end{array}$ & $\begin{array}{l}8.19 \times 10^{-12}- \\
6.91 \times 10^{-4}\end{array}$ & $\begin{array}{l}1.41 \times 10^{-4}- \\
1.91 \times 10^{-3}\end{array}$ & $\begin{array}{l}1.06 \times 10^{-12}- \\
2.85 \times 10^{-11}\end{array}$ & $\begin{array}{l}7.28 \times 10^{-6}- \\
6.14 \times 10^{-4}\end{array}$ & $\begin{array}{l}\text { Iwegbue et } \\
\text { al. (2016) }\end{array}$ \\
\hline & Soil & - & - & - & - & - & $4.55 \times 10^{-4}$ & - & - & $5.07 \times 10^{-4}$ & $\begin{array}{l}\text { Olawoyin } \\
\text { et al. } \\
(2012)\end{array}$ \\
\hline & Dust & - & - & - & $\begin{array}{l}3.16 \times 10^{-7}- \\
6.38 \times 10^{-4}\end{array}$ & $\begin{array}{l}8.79 \times 10^{-15}- \\
6.35 \times 10^{-12}\end{array}$ & $\begin{array}{l}9.12 \times 10^{-8}- \\
8.34 \times 10^{-4}\end{array}$ & $\begin{array}{l}1.52 \times 10^{-4}- \\
1.14 \times 10^{-3}\end{array}$ & $\begin{array}{l}3.53 \times 10^{-14}- \\
1.33 \times 10^{-11}\end{array}$ & $\begin{array}{l}1.34 \times 10^{-6}- \\
5.93 \times 10^{-4}\end{array}$ & $\begin{array}{l}\text { Iwegbue } \\
\text { and Obi } \\
(2016)\end{array}$ \\
\hline & Soil & $<1$ & $<1$ & $<1$ & $\begin{array}{l}4.36 \times 10^{-3}- \\
2.45 \times 10^{-3}\end{array}$ & $\begin{array}{l}3.84 \times 10^{-10}- \\
2.17 \times 10^{-8}\end{array}$ & $\begin{array}{l}1.59 \times 10^{-3}- \\
8.9 \times 10^{-2}\end{array}$ & $\begin{array}{l}3.01 \times 10^{-4}- \\
1.69 \times 10^{-2}\end{array}$ & $\begin{array}{l}4.23 \times 10^{-10^{-}} \\
2.39 \times 10^{-8}\end{array}$ & $\begin{array}{l}1.56 \times 10^{-4}- \\
8.74 \times 10^{-3}\end{array}$ & $\begin{array}{l}\text { Emoyan } \\
(2020)\end{array}$ \\
\hline & Soil & - & - & - & $\begin{array}{l}4.31 \times 10^{-3}- \\
3.54 \times 10^{-2}\end{array}$ & - & - & $\begin{array}{l}5.99 \times 10^{-4}- \\
8.90 \times 10^{-3}\end{array}$ & - & - & $\begin{array}{l}\text { Owhoeke } \\
\text { et al. } \\
(2020)\end{array}$ \\
\hline Crops & Mushroom & - & - & - & - & - & - & $\begin{array}{l}1.56 \times 10^{-8}- \\
1.73 \times 10^{-6}\end{array}$ & - & - & $\begin{array}{l}\text { Igbiri et al. } \\
(2017)\end{array}$ \\
\hline
\end{tabular}


17<smiles>C[C@@H]1CC1N</smiles>

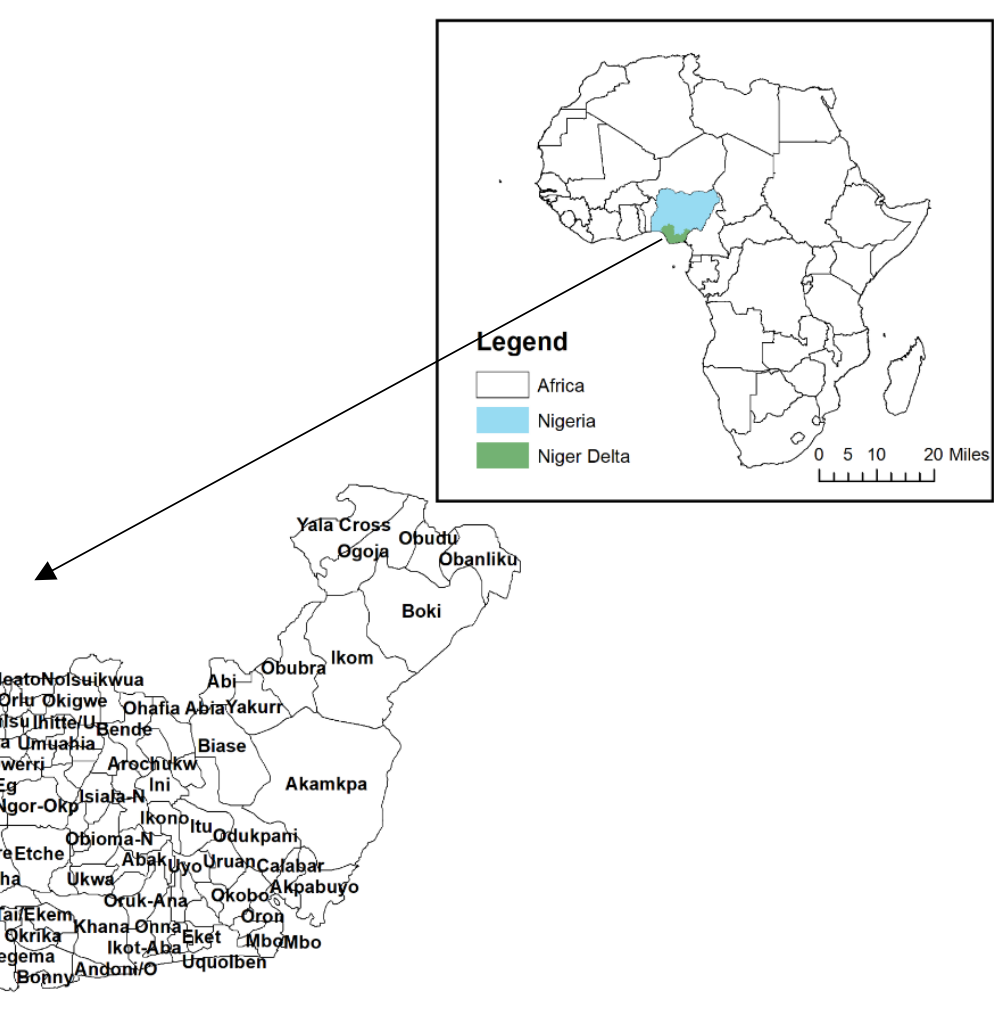

Legend

Akekonest

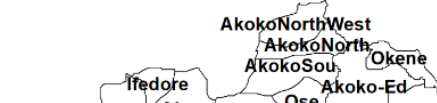

IleOluji/OkeigboAkure Owo Ose AtsakoE

Ondo Idanre OwwanWestEtsakowe Odigbo Esantort Inale Irele OviaNort EsanWest EsanSout

QviaSouth-West IkaSouthaniochan IrajeEseodo Orhionmw Oshimil Seodg Oredo Edo IkaNorthaniochas WarriNorth/Sapere. Now NokwaWe IdeatoNorstikwu

okpe Orlurokigwe

Warrisou NdokwaEa On WarriSouth GigheliNolsakoNor Oguta mua

Burut tronelis Isokosou

Burutu ten

Bomadivorthern

Ekeremer Ahoada Emyoh Abak Uhy OU ruancarabar

Ekeremor A Enoada Emuoha Ukwa Ápabuyo

Southernljaw A Asaris To Tairkem Khana Onna Oron ?

Southernljaw Brass AkukutorDegema Anot_Aba Usiolben

18

Local Government Areas in Niger Delta

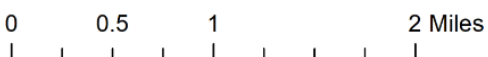

19 Fig. 1 Map of Niger Delta showing the various Local Government Areas 
21

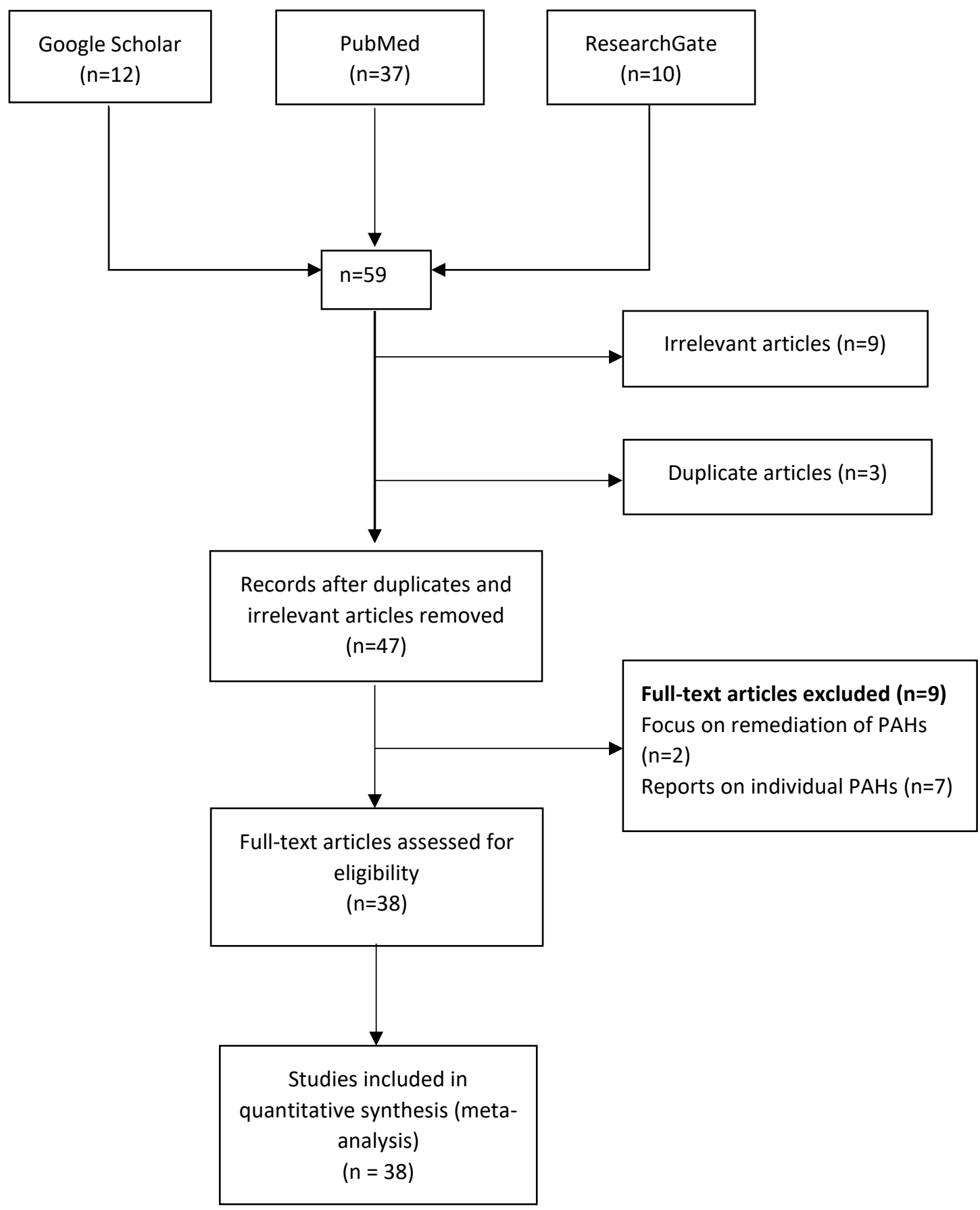


22 Fig. 2 Flow chart of article selection (Adapted from Moher et al. 2009)

23

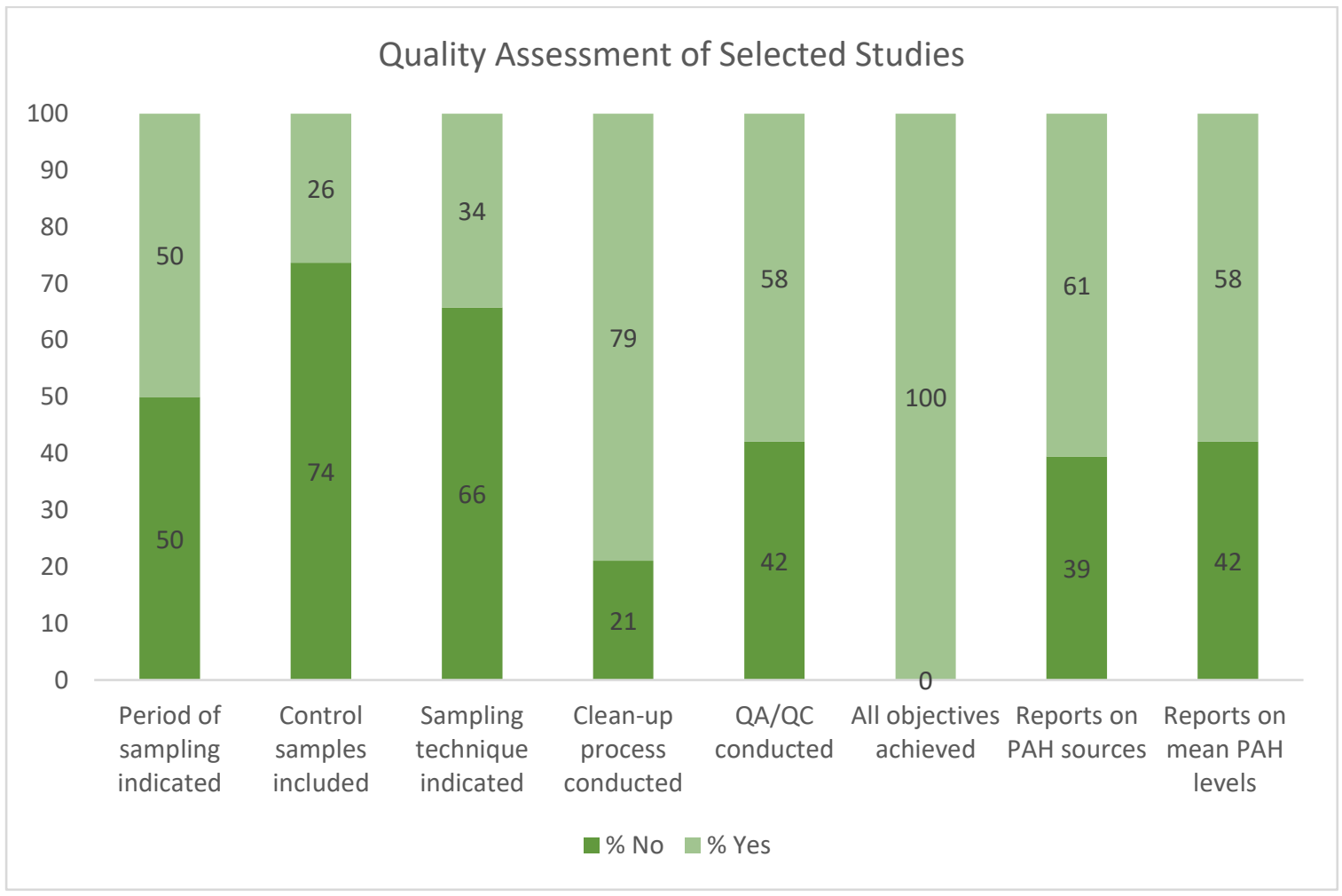

25

Fig. 3 Quality assessment of selected studies

26

27

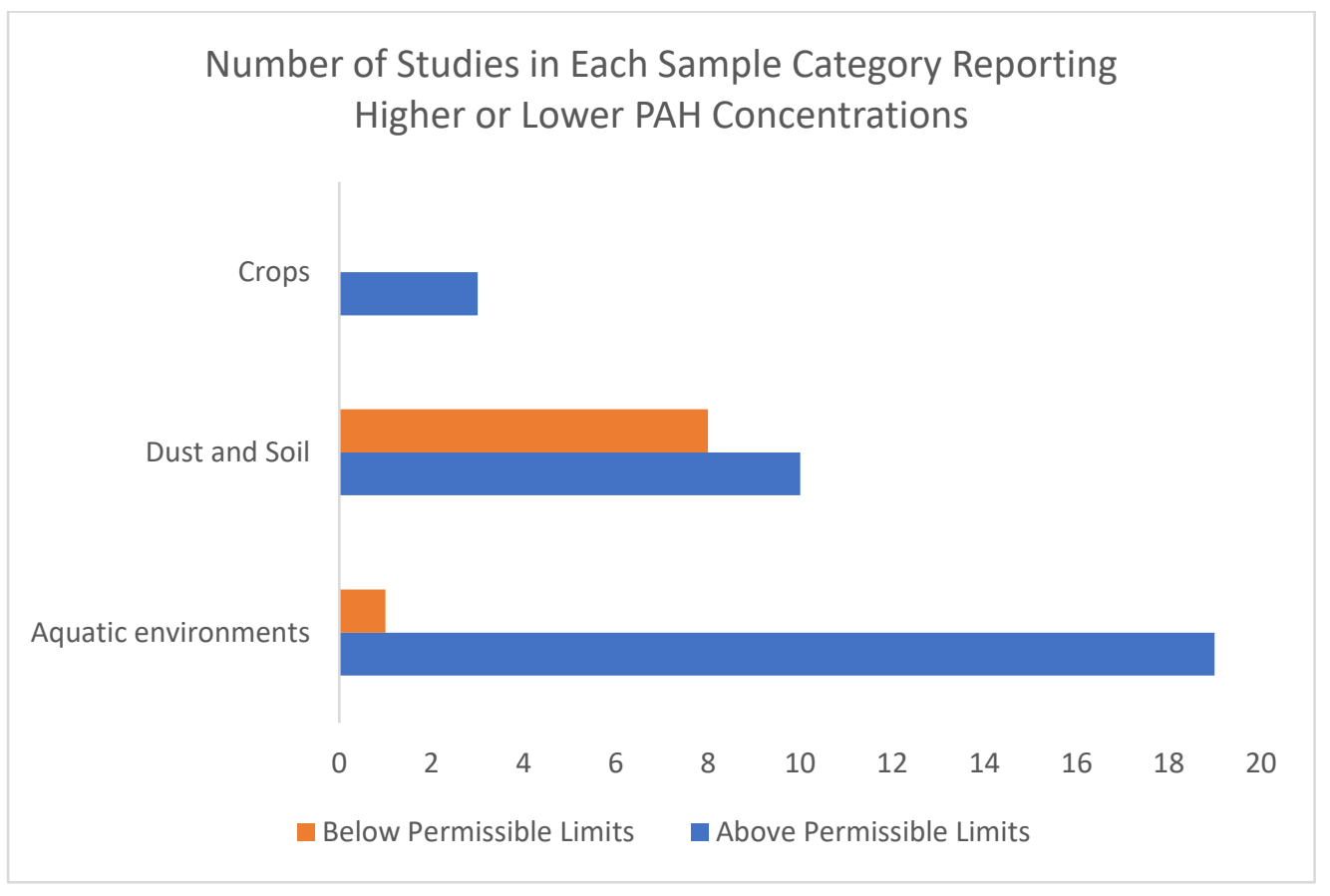

29 Fig. 4 Number of studies in each sample category reporting higher or lower PAH concentrations as compared to the permissible limits 
Number and Types of PAHs Recorded by Sample Category

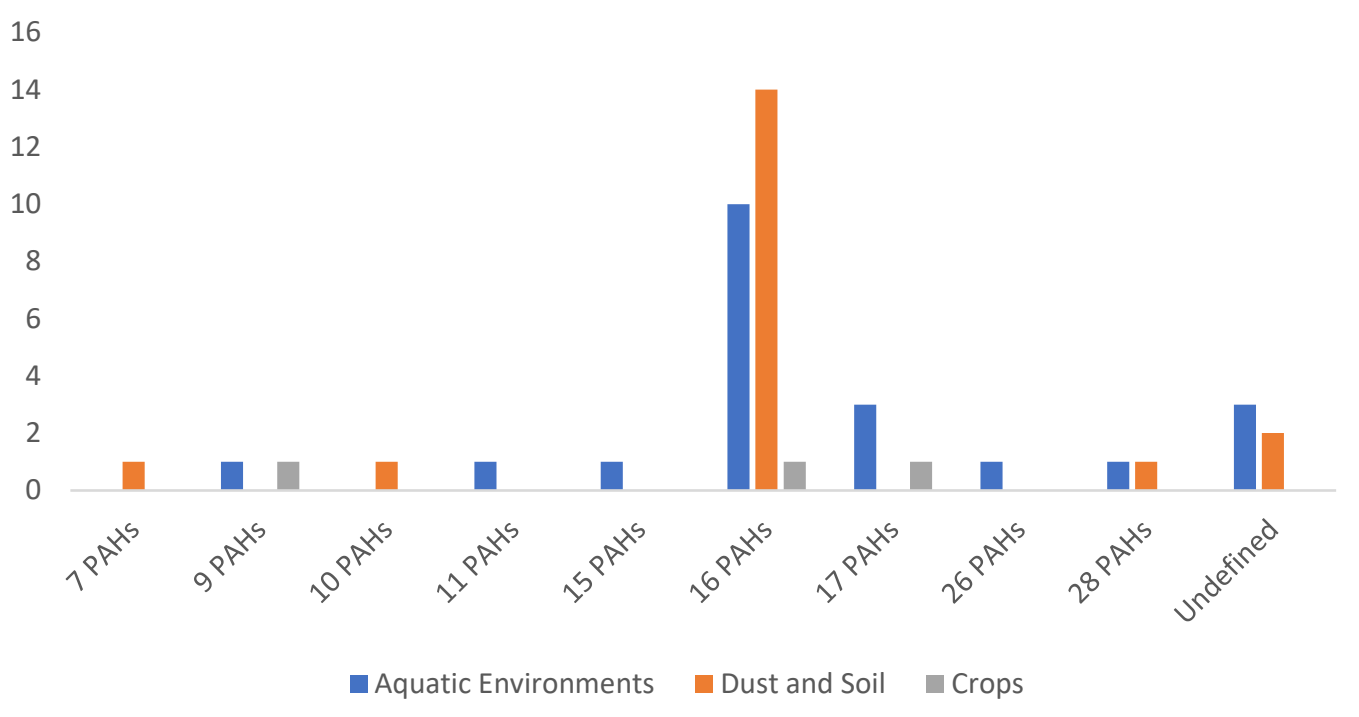

31

32 Fig. 5 Number and types of PAHs recorded by each sample category

33

34

35 